\title{
Relationships between Arctic sea ice drift and strength modelled by NEMO-LIM3.6
}

\author{
David Docquier $^{1}$, François Massonnet ${ }^{1,2}$, Antoine Barthélemy ${ }^{1}$, Neil F. Tandon ${ }^{3}$, Olivier Lecomte ${ }^{1}$, and \\ Thierry Fichefet ${ }^{1}$ \\ ${ }^{1}$ Université catholique de Louvain (UCL), Earth and Life Institute (ELI), Georges Lemaître Centre for Earth and Climate \\ Research (TECLIM), Louvain-la-Neuve, Belgium \\ ${ }^{2}$ Barcelona Supercomputing Centre - Centro Nacional de Supercomputación (BSC-CNS), \\ Earth Sciences Department, Barcelona, Spain \\ ${ }^{3}$ Environment and Climate Change Canada (ECCC), Climate Research Division, Toronto, Canada
}

Correspondence: David Docquier (david.docquier@uclouvain.be)

Received: 7 April 2017 - Discussion started: 25 April 2017

Revised: 3 November 2017 - Accepted: 6 November 2017 - Published: 11 December 2017

\begin{abstract}
Sea ice cover and thickness have substantially decreased in the Arctic Ocean since the beginning of the satellite era. As a result, sea ice strength has been reduced, allowing more deformation and fracturing and leading to increased sea ice drift speed. We use the version 3.6 of the global ocean-sea ice NEMO-LIM model (Nucleus for European Modelling of the Ocean coupled to the Louvain-laNeuve sea Ice Model), satellite, buoy and submarine observations, as well as reanalysis data over the period from 1979 to 2013 to study these relationships. Overall, the model agrees well with observations in terms of sea ice extent, concentration and thickness. The seasonal cycle of sea ice drift speed is reasonably well reproduced by the model. NEMOLIM3.6 is able to capture the relationships between the seasonal cycles of sea ice drift speed, concentration and thickness, with higher drift speed for both lower concentration and lower thickness, in agreement with observations. Model experiments are carried out to test the sensitivity of Arctic sea ice drift speed, thickness and concentration to changes in sea ice strength parameter $P^{*}$. These show that higher values of $P^{*}$ generally lead to lower sea ice deformation and lower sea ice thickness, and that no single value of $P^{*}$ is the best option for reproducing the observed drift speed and thickness. The methodology proposed in this analysis provides a benchmark for a further model intercomparison related to the relationships between sea ice drift speed and strength, which is especially relevant in the context of the upcoming Coupled Model Intercomparison Project 6 (CMIP6).
\end{abstract}

\section{Introduction}

The motion or drift of sea ice results from a balance of wind stress, ocean stress, ice internal stress, Coriolis force and ocean surface tilt. Scale analysis shows that the main drivers of drift are the first three terms, and that both Coriolis force and ocean surface tilt are an order of magnitude smaller (Steele et al., 1997; Leppäranta, 2011). For individual ice floes and for ice fields with low compactness, ice internal stress is generally neglected: sea ice is in free drift. Otherwise, ice internal stress is an important driver of sea ice motion and is a key element of the relationships between sea ice drift speed and strength described hereafter. In this paper, we focus on the Arctic Ocean, for which a sufficient network of observations is available.

To first order, sea ice strength mainly depends on two quantities, namely sea ice concentration (defined as the relative amount of ocean area covered by sea ice) and sea ice thickness. A decrease in concentration or thickness, as observed in recent decades in the Arctic Ocean (Stroeve et al., 2012; Vaughan et al., 2013; Lindsay and Schweiger, 2015), leads to a reduced ice strength and internal stress, which allows more deformation and fracturing within the ice, hence larger sea ice drift speed (Rampal et al., 2011; Spreen et al., 2011; Kwok et al., 2013). This in turn could provide higher export of sea ice out of the Arctic Basin (Rampal et al., 2011), resulting in lower sea ice concentration and further thinning (Langehaug et al., 2013). However, this hypothetical positive feedback, which we call "drift-strength feedback", has been 
poorly studied and its existence has not been shown in observations.

A clear increase in Arctic sea ice drift speed has been detected since the 1950s using buoy observations and satellite measurements (Häkkinen et al., 2008; Rampal et al., 2009, 2011; Spreen et al., 2011; Vihma et al., 2012; Kwok et al., 2013; Olason and Notz, 2014). While increased wind speed seems to be the likely cause of the increase in sea ice motion before 1990, the reduced ice strength (most likely caused by reduced thickness and concentration) is the dominant driver since then (Döscher et al., 2014). It has been suggested that an increase in drift speed leads to higher sea ice export from the Arctic Basin, which mainly occurs through Fram Strait. However, a distinction needs to be made between area and volume exports: area export is the product of sea ice drift speed, concentration and transect length, while volume export is the product of area export and ice thickness. Several studies show an increase of ice area export at Fram Strait since the late 1970s (Langehaug et al., 2013; Krumpen et al., 2016; Smedsrud et al., 2016), while Kwok et al. (2013) show a small decrease between 1982 and 2009. In terms of volume export, the amount of studies is limited by the relatively low ice thickness temporal coverage at Fram Strait. Spreen et al. (2009) show no significant change in ice volume export between 1990 and 2008. The review from Döscher et al. (2014) addresses this question and concludes that there is no significant long-term trend in sea ice area export due to a balance between increased drift speed and decreased concentration, while volume export slightly falls due to a decreased sea ice thickness. A summary of these studies related to drift speed trend and its cause as well as sea ice export at Fram Strait is provided in Table 1.

Olason and Notz (2014) investigate the relationships between Arctic sea ice drift speed, concentration and thickness using satellite and buoy observations. They show that both seasonal and recent long-term changes in sea ice drift are primarily correlated to changes in sea ice concentration and thickness. On seasonal timescales, when sea ice concentration is low (from June to November), drift speed increases with decreasing concentration, while for high concentration (from December to March), drift speed changes are largely driven by changes in thickness (higher drift speed with lower thickness).

An analysis of sea ice output from the Coupled Model Intercomparison Project 3 (CMIP3) multi-model dataset suggests that in those models thicker and more packed sea ice drifts faster, contrary to what is observed (Rampal et al., 2011). The same study also shows that models with a stronger long-term thinning trend do not exhibit faster drift speed, suggesting that the coupling between drift and strength is underestimated in CMIP3 models. According to the authors, this could explain the too low trends in sea ice area, thickness and drift speed.

The main goal of this study is to investigate the relationships between Arctic sea ice drift speed and strength us- ing version 3.6 of the Nucleus for European Modelling of the Ocean coupled to the Louvain-la-Neuve sea Ice Model (NEMO-LIM3.6). We first apply the methodology developed by Olason and Notz (2014) to the model to see how changes in ice drift speed are related to changes in ice concentration and thickness throughout the year. We extend this methodology by developing new process-based metrics that allow a direct comparison of the model against observations. However, good agreement between the model and observations is not a guarantee that the model is able to capture all the features of drift-strength relationships. Thus, we carry on additional sensitivity experiments where initial ice strength is varied, and we investigate the impact on the resulting drift speed, concentration and thickness of sea ice. The methodology proposed in this analysis provides a benchmark for further model intercomparison related to drift-strength relationships and could be used in the analysis of sea ice outputs from the upcoming High Resolution Model Intercomparison Project (HighResMIP) (Haarsma et al., 2016) and CMIP6 Sea-Ice Model Intercomparison Project (SIMIP) (Notz et al., 2016).

In Sect. 2 we describe the model, the reference products (observations and reanalyses) as well as the diagnostics and metrics. Then, results from the model evaluation against different observational and reanalysis datasets are presented (Sect. 3.1). Section 3.2 details the relationships between drift speed and strength on seasonal timescales. Results from the sensitivity experiments are shown in Sect. 3.3. These results are discussed in Sect. 4. Finally, a summary is provided in Sect. 5.

\section{Methodology}

\subsection{Model and sensitivity experiments}

The model used in this study is version 3.6 of the global ocean-sea ice coupled model NEMO-LIM (SVN revision 6631). The ocean component NEMO3.6 is a finite difference, hydrostatic, primitive equation model (Madec, 2016). The sea ice component LIM3.6 is a dynamic-thermodynamic model that uses the elastic-viscous-plastic (EVP) rheology on a C-grid and includes an explicit ice thickness distribution (ITD) (Vancoppenolle et al., 2009; Rousset et al., 2015).

The atmospheric forcing is the Drakkar Forcing Set (DFS) 5.2 (Dussin et al., 2016), which is based on the ERA-Interim atmospheric reanalysis dataset. The model is run on the global tripolar eORCA1 grid (about $1^{\circ}$ spatial resolution) from January 1958 to December 2015. Model outputs that are used in this study are sea ice concentration, thickness and velocity components over the period 1979-2013. This period is chosen to match the satellite period. Sea ice thickness used in this study is the sea ice volume per grid cell area taking into account open water (named "sivol" according to SIMIP nomenclature) rather than the actual thickness 
Table 1. Summary of published literature providing observational drift speed trend and its cause, as well as area and volume export of sea ice at Fram Strait.

\begin{tabular}{|c|c|c|c|c|}
\hline Reference & Drift speed & Cause of drift increase & Area export & Volume export \\
\hline Häkkinen et al. (2008) & $\begin{array}{l}\text { 1950-2006: } \\
\text { significant positive trend }\end{array}$ & Wind & & \\
\hline Spreen et al. (2009) & & & & $\begin{array}{l}\text { 1990-2008: } \\
\text { no significant change }\end{array}$ \\
\hline Kwok (2009) & & & $\begin{array}{l}\text { 1979-2007: } \\
\text { no significant trend }\end{array}$ & \\
\hline Rampal et al. (2009) & $\begin{array}{l}\text { 1979-2007: } \\
+17 \% \text { decade }^{-1} \text { in winter } \\
+8.5 \% \text { decade }^{-1} \text { in sum- } \\
\text { mer }\end{array}$ & Ice strength & & \\
\hline Spreen et al. (2011) & $\begin{array}{l}\text { 1992-2009: } \\
+10.6 \% \text { decade }^{-1}\end{array}$ & $\begin{array}{l}\text { Ice strength (first) } \\
\text { Wind (second) }\end{array}$ & & \\
\hline Gimbert et al. (2012) & & Ice strength & & \\
\hline Polyakov et al. (2012) & & & 1979-1995: increase & \\
\hline Vihma et al. (2012) & 1989-2009: increase & $\begin{array}{l}\text { Ice strength (first) } \\
\text { Wind (second) }\end{array}$ & & \\
\hline Kwok et al. (2013) & $\begin{array}{l}\text { 1982-2009: } \\
+6.2 \% \text { decade }^{-1} \text { in winter } \\
+3.6 \% \text { decade }^{-1} \text { in sum- } \\
\text { mer }\end{array}$ & Not wind & $\begin{array}{l}\text { 1982-2009: } \\
\text { small decrease }\end{array}$ & \\
\hline Langehaug et al. (2013) & & & $\begin{array}{l}\text { 1957-2005: } \\
\text { small increase }\end{array}$ & \\
\hline Döscher et al. (2014) & Increase & $\begin{array}{l}\text { From 1990: ice strength } \\
\text { Before 1990: wind }\end{array}$ & No long-term trend & Decrease \\
\hline Olason and Notz (2014) & $\begin{array}{l}\text { 1979-2011: } \\
+1.1 \mathrm{~km} \mathrm{~d}^{-1} \text { decade }^{-1} \text { in } \\
\text { summer } \\
+0.4 \mathrm{~km} \mathrm{~d}^{-1} \text { decade }^{-1} \text { in } \\
\text { winter }\end{array}$ & Ice strength & & \\
\hline Krumpen et al. (2016) & & & $\begin{array}{l}\text { 1980-2012: } \\
\text { significant positive } \\
\text { trend }\end{array}$ & \\
\hline Smedsrud et al. (2016) & Increase & Wind & $\begin{array}{l}\text { 1979-2014: } \\
+6 \% \text { decade }^{-1}\end{array}$ & \\
\hline
\end{tabular}

("sithick"), since the former is more physical in representing global relationships between sea ice dynamics and thermodynamics, and this is the variable used in the formulation of sea ice strength detailed below.

Four different simulations are performed in order to test the sensitivity of sea ice drift speed, thickness and concentration to changes in initial sea ice strength $P$. The latter is computed as a function of ice thickness $h$ and concentration
$A$ using the formulation of Hibler (1979):

$P=P^{*} h \exp [-C(1-A)]$,

where $C(=20)$ and $P^{*}$ are fixed empirical constants. Five different values of $P^{*}\left(5.5,20,27.5,45\right.$ and $\left.100 \mathrm{kN} \mathrm{m}^{-2}\right)$ are used in order to perform sensitivity experiments to test how a change in the strength parameterization impacts the ice drift speed, concentration and thickness. The experiment with $P^{*}=20 \mathrm{kN} \mathrm{m}^{-2}$ is the control simulation that is anal- 
ysed in Sects. 3.1 and 3.2. The results from the other four experiments are presented in Sect. 3.3.

The value of $P^{*}=20 \mathrm{kN} \mathrm{m}^{-2}$ is the commonly used value in NEMO-LIM3.6 and has been chosen through tuning of mean sea ice thickness and mean Fram Strait ice export (M. Vancoppenolle, personal communication, 2017). This is also the value used in the viscous-plastic models of SIMIP (Kreyscher et al., 1997) as well as in more recent modelling studies (Lipscomb et al., 2007; Juricke et al., 2013). Hibler and Walsh (1982) find that $P^{*}=27.5 \mathrm{kN} \mathrm{m}^{-2}$ provides the best agreement between their $222 \mathrm{~km}$ resolution sea ice model and observations from the Soviet ice station NP-22 in terms of mean drift rates in 1974-1975. Tremblay and Hakakian (2006) find that the most likely value of $P^{*}$ lies in the range $30-45 \mathrm{kN} \mathrm{m}^{-2}$ based on satellite observations. Therefore, the value of $P^{*}$ in Eq. (1) is highly uncertain and not a single value is considered as a reference (Feltham, 2008). The different sensitivity experiments carried out in this study account for this uncertainty.

The experiment with $P^{*}=5.5 \mathrm{kN} \mathrm{m}^{-2}$ provides lower ice strength $P$ than the control simulation $\left(P^{*}=20 \mathrm{kN} \mathrm{m}^{-2}\right)$ for a given thickness. It is the lowest value used by Steele et al. (1997) in their model sensitivity study, corresponding to the value of $27.5 \mathrm{kN} \mathrm{m}^{-2}$ (Hibler and Walsh, 1982) divided by 5 . The experiment with $P^{*}=27.5 \mathrm{kN} \mathrm{m}^{-2}$ gives higher ice strength $P$ than the control simulation and corresponds to the value found by Hibler and Walsh (1982). The experiment with $P^{*}=45 \mathrm{kN} \mathrm{m}^{-2}$ is the largest value of the likely range found by Tremblay and Hakakian (2006). The experiment with $P^{*}=100 \mathrm{kN} \mathrm{m}^{-2}$ is close to the highest value of Steele et al. (1997).

\subsection{Reference products}

In this study, we use several observational and reanalysis datasets for a given variable in order to evaluate model results, following the recommendations of Notz (2015) and Massonnet et al. (2016).

\subsubsection{Sea ice drift speed}

For sea ice drift speed, the International Arctic Buoy Programme (IABP) $\mathrm{C}$ buoy dataset is retrieved from the National Snow and Ice Data Center (NSIDC) (Tschudi et al., 2016). This dataset provides 12 -hourly sea ice velocity vectors derived from buoy positions over the period extending from 1979 to 2015 . Ice motion derived from buoys is more accurate than that obtained from satellites (error of less than $1 \mathrm{~cm} \mathrm{~s}^{-1}$ for the average velocity over $24 \mathrm{~h}$ according to NSIDC), but the coverage is very limited and the number of buoys and their locations varies from year to year. In addition, buoys have not been placed on ice in the Eastern Arctic. The daily mean sea ice drift speed is computed for each buoy from 12-hourly data.
We also include the merged product from Tschudi et al. (2016), which provides daily sea ice motion vectors on the Equal-Area Scalable Earth (EASE) Grid with a resolution of $25 \mathrm{~km}$ from 1979 to 2015 . This dataset, available on the NSIDC website, is a compilation of velocity vectors from IABP buoy data, satellite observations from Advanced Microwave Scanning Radiometer - Earth Observing System (AMSR-E), Advanced Very High Resolution Radiometer (AVHRR), Scanning Multichannel Microwave Radiometer (SMMR), Special Sensor Microwave/Imager (SSM/I) and Special Sensor Microwave Imager Sounder (SSMIS), as well as NCEP-NCAR reanalysis. The different sources of data are combined through a weighting that depends on the accuracy of each dataset. This merged product suffers from artifacts of the method used to incorporate buoy data, especially in terms of ice divergence and convergence (Szanyi et al., 2016). In our paper, we call this product "NSIDC".

We use the low-resolution sea ice drift product (OSI-405b) from the European Organisation for the Exploitation of Meteorological Satellites Ocean and Sea Ice Satellite Application Facility (EUMETSAT OSI SAF, 2015b; Lavergne et al., 2010). This dataset covers the period from October 2006 to the present. No data are available from May to September (inclusive) for the Arctic region due to high atmospheric liquid water content and to ice surface melting. Despite this low temporal coverage compared to other sea ice drift products, the quality of OSI SAF data is superior to other satellite products based on a recent uncertainty estimate (Sumata et al., 2014). This dataset combines satellite measurements of both the brightness temperature using passive microwave instruments from SSM/I, SSMIS, AMSR-E and Advanced Microwave Scanning Radiometer 2 (AMSR2) and the radar backscatter using Advanced Scatterometer (ASCAT). Sea ice drift vectors are provided every 2 days at a spatial resolution of $62.5 \mathrm{~km}$, and we calculate daily mean drift speed from these data. We compared modelled drift speed averaged over 2 days to original OSI SAF data but we did not find any significant difference. Since we mainly compare the modelled sea ice drift speed to buoy data instead of satellite data (which have a lower temporal coverage), we have decided to keep daily averages of sea ice drift speed as a benchmark for comparison.

\subsubsection{Sea ice concentration}

For sea ice concentration, the global reprocessed dataset (OSI-409-a) from OSI SAF (EUMETSAT OSI SAF, 2015a) is used. It covers the period from October 1978 to April 2015 using passive microwave data from SMMR, SSM/I and SSMIS. The OSI SAF algorithm to retrieve concentration from brightness temperature is a linear combination of the Bootstrap algorithm in frequency mode over open water (Comiso, 1986; Comiso et al., 1997) and the Bristol algorithm over ice (Smith, 1996). This is one of the best concentration algorithms in terms of precision (standard deviation) according to 
a recent evaluation (Ivanova et al., 2015). The spatial resolution for this dataset is $10 \mathrm{~km}$. We compute the monthly mean concentration from daily data.

We also retrieve the monthly mean sea ice concentration (1979-2015) computed from the AMSR-E Bootstrap algorithm with daily varying tie-points (Comiso, 2015). This dataset is derived using measurements from SMMR, SSM/I and SSMIS. Due to orbit inclination, data do not cover the region north of $84.5^{\circ} \mathrm{N}$ for SMMR and $87.2^{\circ} \mathrm{N}$ for SSM/I and SSMIS. Data are gridded on the SSM/I polar stereographic grid with a $25 \mathrm{~km}$ resolution. Largest errors related to this dataset are found in summer when melt is underway. In the rest of the paper, this product is referred to as "Bootstrap".

\subsubsection{Sea ice thickness}

For sea ice thickness, we use the multiple regression model of Rothrock et al. (2008), based on 34 US Navy submarine cruises spanning the period 1975-2000 within the Scientific Ice Expeditions (SCICEX) box. This dataset includes more than 2000 records of sea ice draft (mostly in spring and autumn) measured from the first-return echo. A positive mean bias of $0.29 \mathrm{~m}$ in ice draft is identified by Rothrock and Wensnahan (2007) and is taken into account in our study. Sea ice thickness is derived from the draft using the methodology of Rothrock et al. (2008).

The gridded data at a spatial resolution of $25 \mathrm{~km}$ from 10 Ice, Cloud, and land Elevation Satellite (ICESat) campaigns is also used (Kwok et al., 2009). The Geoscience Laser Altimeter System (GLAS) is the laser altimeter on board ICESat that measures sea ice freeboard height, from which sea ice thickness is derived using snow depth and densities of ice, snow and water. The coverage period is limited to the months of October-November and February-March starting in late September 2003 and ending in March 2008. The Kwok et al. (2009) dataset provides the mean sea ice thickness for each of the ten campaigns. The mean absolute uncertainty of sea ice thickness derived from ICESat is $0.21 \mathrm{~m}$ in October-November and $0.28 \mathrm{~m}$ in February-March (Zygmuntowska et al., 2014).

Due to the spatial and temporal gaps of sea ice thickness measurements and the high uncertainty inherent to thickness retrievals (Stroeve et al., 2014; Zygmuntowska et al., 2014), we also use monthly mean thickness derived from the PanArctic Ice-Ocean Modeling and Assimilation System (PIOMAS) over the period 1979-2013. PIOMAS is a multicategory thickness and enthalpy distribution sea ice model coupled to the Parallel Ocean Program developed at the Los Alamos National Laboratory (Zhang and Rothrock, 2003). The model assimilates observed sea ice concentration and sea surface temperature and is driven by daily NCEP-NCAR reanalysis surface forcing fields. The mean horizontal resolution in the Arctic is $22 \mathrm{~km}$. PIOMAS data are primarily model generated, and must therefore be interpreted with caution. Nevertheless, sea ice thickness from PIOMAS agrees well with ICESat data over the region for which submarine data are available (Schweiger et al., 2011) and constitutes a valuable tool in our analysis. Given the uncertainties of both observational products and PIOMAS, using all of the products together allows us to obtain a range of "reference values" that is more reliable than the range based on observational products alone.

\subsection{Diagnostics and metrics}

A diagnostic is a measure of one characteristic of a model or an observational dataset, while a metric is a scalar number that compares a diagnostic to some reference (typically observations). In this study, we use both "standard" diagnostics as well as process-based diagnostics and metrics. The standard diagnostics that we use are as follows:

- sea ice extent, defined as the total area of ocean with sea ice concentration higher than 0.15

- sea ice area, which is the total area of sea ice cover, computed due to uncertainties linked to sea ice extent (Notz, 2014)

- sea ice concentration, which is the relative amount of ocean area covered by sea ice

- sea ice thickness, defined as the sea ice volume per grid cell area

- sea ice drift speed, which is the velocity of sea ice computed at the daily timescale.

It is important to note that for drift speed, all values given in this study are computed from the daily mean components of sea ice velocity $u_{\mathrm{d}}$ and $v_{\mathrm{d}}$ :

$D_{\mathrm{d}}=\sqrt{u_{\mathrm{d}}^{2}+v_{\mathrm{d}}^{2}}$,

where $D_{\mathrm{d}}$ is the daily mean drift speed. Monthly mean drift speed computed from the daily components of sea ice velocity is approximately twice as high as monthly mean drift speed computed from monthly components of sea ice velocity with NEMO-LIM3.6 due to higher temporal variability at the daily timescale (Fig. 1). A recent analysis also shows that such a factor of 2 is also apparent within the CMIP5 models (Tandon et al., 2017). Using daily components is more accurate for our study because we can capture synoptic-scale variability.

From daily values of these standard diagnostics, we compute monthly means temporally averaged over the period 1979-2013. The maps shown in this paper (Figs. 3, 6) provide monthly means averaged over three consecutive months for winter (January, February, March) and summer (July, August, September) for each grid cell. The plots of mean seasonal cycles (Figs. 2, 5, 7) provide spatial means over the SCICEX box (Rothrock et al., 2008), which is also the domain used by Olason and Notz (2014) in their study. The 


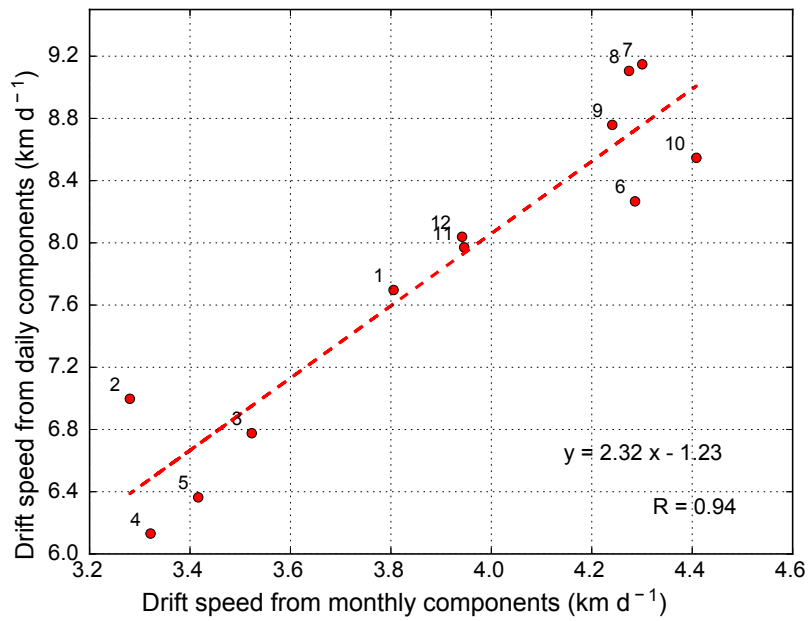

Figure 1. Scatter plot of modelled (NEMO-LIM3.6) monthly mean sea ice drift speed computed from daily components against drift speed based on monthly components. Data are temporally averaged over the period 1979-2013 and spatially averaged over the SCICEX box. Numbers denote months. The dashed line represents the linear regression. The equation of the linear regression and the Pearson correlation coefficient between both variables are shown in the lower right corner.

SCICEX box is representative of sea ice processes happening in the central Arctic region and is well covered by observational datasets of sea ice concentration, thickness and drift speed. All maps in this study show the contours of the SCICEX box. We have also tested computing spatial means over a much wider domain taking into account all grid cells between 50 and $90^{\circ} \mathrm{N}$ with a concentration threshold of $A \geq 0.15$. Unless specifically mentioned in the text, the default domain that is used in the following sections is the SCICEX box. Since IABP buoy data are not gridded, we use all buoys within the SCICEX box to compute the spatial mean over that region. We acknowledge that comparing buoy and model drift speed has to be done with caution, as buoys measure the drift speed at one particular location while the model is meant to give the grid-cell average. For computing spatial means, a weight is given to each grid cell proportional to the grid cell area.

Based on the "standard" diagnostics described above, we use two process-based diagnostics in order to quantify the ability of NEMO-LIM3.6 to capture the relationships between sea ice drift speed and strength in the Arctic. The first process-based diagnostic is a scatter plot of sea ice drift speed against sea ice concentration for each month of the mean seasonal cycle as in Olason and Notz (2014). The second diagnostic is similar to the first diagnostic, with sea ice thickness instead of concentration. All values are spatially averaged over the SCICEX box and temporally averaged over the period 1979-2013. A key difference with Olason and Notz (2014) is that we do not normalize drift speed by wind fric- tion speed since our findings were not sensitive to such normalization. These two diagnostics are presented in Figs. 4 and 9.

Based on the previous process-based diagnostics, four metrics are computed over the mean seasonal cycle. The first metric $s_{A}$ measures the ratio of the modelled driftconcentration slope to the observed drift-concentration slope. The closer the ratio to 1 , the closer the model to the observations. The second metric $s_{h}$ is similar to the first metric, except that the ratio involves drift-thickness slopes.

The third and fourth metrics quantify the normalized distances (in \%) between the model and observations for both the drift-concentration $\left(\epsilon_{A}\right)$ and drift-thickness $\left(\epsilon_{h}\right)$ relationships respectively:

$$
\begin{aligned}
\epsilon_{A} & =\frac{1}{n} \sum_{i=1}^{n} \sqrt{\left|\frac{A_{\mathrm{m}, i}-A_{\mathrm{o}, i}}{\overline{A_{\mathrm{o}}}}\right|^{2}+\left|\frac{D_{\mathrm{m}, i}-D_{\mathrm{o}, i}}{\overline{D_{\mathrm{o}}}}\right|^{2}} \times 100, \\
\epsilon_{h} & =\frac{1}{n} \sum_{i=1}^{n} \sqrt{\left|\frac{h_{\mathrm{m}, i}-h_{\mathrm{o}, i}}{\overline{h_{\mathrm{o}}}}\right|^{2}+\left|\frac{D_{\mathrm{m}, i}-D_{\mathrm{o}, i}}{\overline{D_{\mathrm{o}}}}\right|^{2}} \times 100,
\end{aligned}
$$

where $n$ is the number of months (i.e. 12), the $\mathrm{m}$ and o subscripts stand for "model" and "observations" respectively, $\bar{A}, \bar{h}$ and $\bar{D}$ are the mean concentration, thickness and drift speed (respectively) over the 12 months.

These four metrics are computed over the whole year, as well as over summer only (May-September) and winter only (November-March). The results from these metrics for the sensitivity experiments are shown in Fig. 10. Unless explicitly mentioned in the text, the metric results presented below correspond to the whole year.

\section{Results}

\subsection{Model evaluation}

The modelled mean seasonal cycle of Arctic sea ice extent is in good agreement with OSI SAF observational reference over the period 1979-2013. However, a too low extent is simulated in August (bias of 1.6 million $\mathrm{km}^{2}$ ) (Fig. 2a, solid lines). This feature is similar to Rousset et al. (2015) who use NEMO-LIM3.6 at $2^{\circ}$ resolution forced by the CORE normal year forcing proposed by Large and Yeager (2009) (we use a resolution of $1^{\circ}$ and DFS5.2 forcing). The amplitude of the modelled seasonal cycle of sea ice area is higher than the observed one (Fig. 2a, dashed lines). Note that satellite observations perform better in winter compared to summer due to the presence of melt ponds in summer (Ivanova et al., 2015).

The modelled mean seasonal cycle of sea ice concentration is very close to OSI SAF observations for all months, except in August when the model underestimates the mean concentration by $\sim 0.15$ (Fig. 2b). This partly explains the too low extent at that time of the year (Fig. 2a). The Bootstrap algorithm provides higher concentration than OSI SAF, 

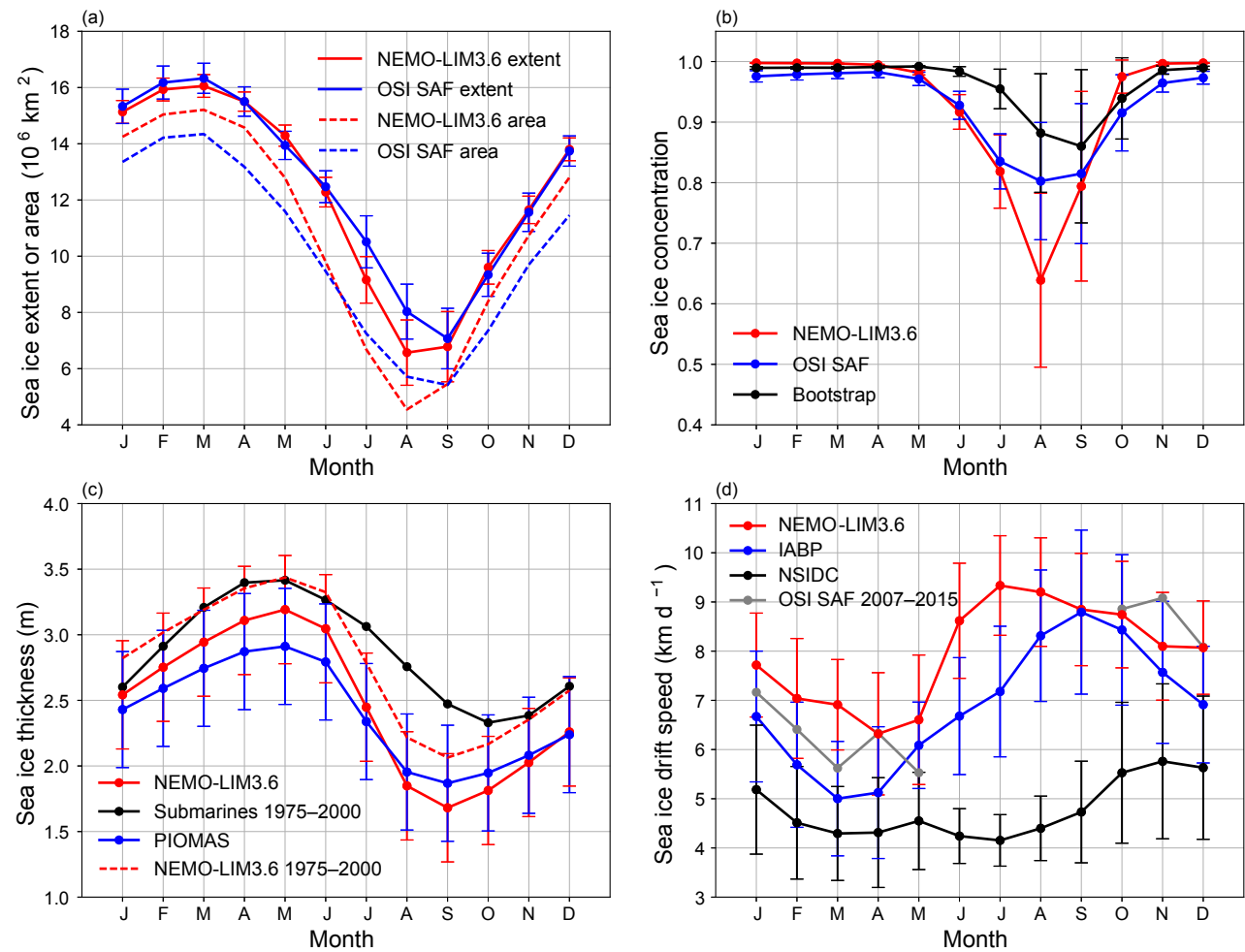

Figure 2. Modelled (NEMO-LIM3.6) and observed monthly mean seasonal cycles of Arctic sea ice (a) extent (total area of grid cells where concentration is higher than 0.15) and area, (b) concentration, (c) thickness (sea ice volume per area) and (d) drift speed averaged over the period 1979-2013 (except for submarine and OSI SAF drift speed observations that span 1975-2000 and 2007-2015 respectively). The spatial mean over the SCICEX box is shown in (b), (c) and (d). Sources for observations and reanalysis: OSI SAF satellite data for extent and concentration, Bootstrap satellite data for concentration, submarines and PIOMAS reanalysis for thickness, IABP buoys, NSIDC (Tschudi et al., 2016) and OSI SAF for drift speed. Error bars show the temporal standard deviation of monthly values. In panel (c), the model seasonal cycle is also computed over 1975-2000 to allow for more direct comparison with submarine observations.

especially in summer, but the spatial coverage is limited due to the absence of data close to the North Pole (Sect. 2.2).

The mean seasonal cycle of sea ice thickness modelled by NEMO-LIM3.6 underestimates the seasonal cycle derived from submarine observations and is in better agreement with PIOMAS with a maximum in May and a minimum in September (Fig. 2c). Compared to PIOMAS, the model overestimates ice thickness when ice is thicker (January to July) and slightly underestimates it when ice is thinner (August to October). We do not show the seasonal cycle of ice thickness from ICESat due to the sparse temporal coverage of these satellite data. However, the model reproduces well the spatial distribution of ICESat thickness with thicker ice north of Greenland and in the Canadian archipelago. The model slightly overestimates the sea ice thickness provided by ICESat in February, March and April (mean bias of $0.07 \mathrm{~m}$ ), and underestimates it in October and November (mean bias of $-0.65 \mathrm{~m})$.

Compared to IABP buoy observations, the model overestimates sea ice drift speed for all months with higher differences from December to March and for June and July
(Fig. 2d). The too strong intensity of the modelled sea ice velocity was already shown with NEMO3.1-LIM2 (Dupont et al., 2015). However, the model captures the seasonality of drift speed with higher values in summer, when concentration and thickness are the lowest, and lower values in winter, when concentration and thickness are high. The minimum modelled drift speed lags the observed minimum by 1 month (March) and the maximum occurs 2 months earlier than the observed maximum (September). The modelled drift speed is also within the range of OSI SAF observations. However, OSI SAF observations cover a much shorter period (20072015) and are not available in summer (June-September). The NSIDC drift speed from Tschudi et al. (2016) does not show a clear seasonal cycle and has values up to $4 \mathrm{~km} \mathrm{~d}^{-1}$ lower than the IABP product. This is also shown by Olason and Notz (2014) with the previous NSIDC product. A spatial analysis shows that NEMO-LIM3.6 overestimates OSI SAF satellite observations for the months when OSI SAF is available (mean bias of $0.91 \mathrm{~km} \mathrm{~d}^{-1}$; Fig. 3c). The main patterns of sea ice circulation, i.e. Beaufort Gyre and Transpolar 

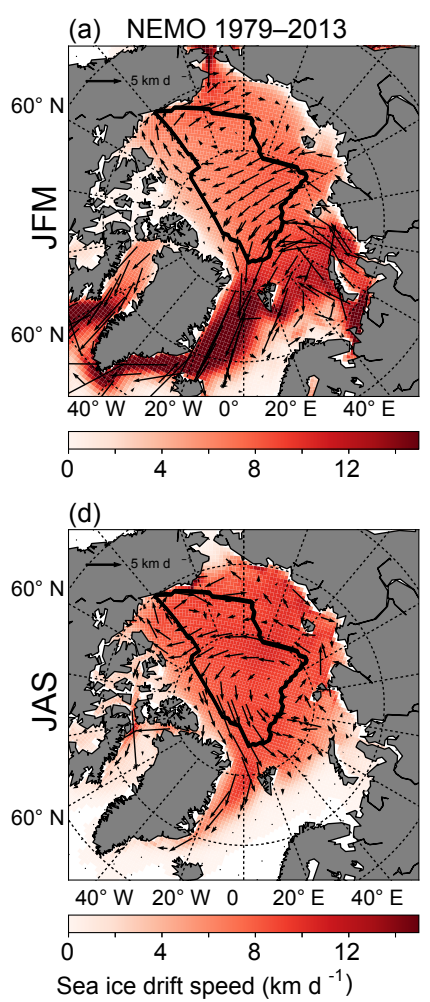
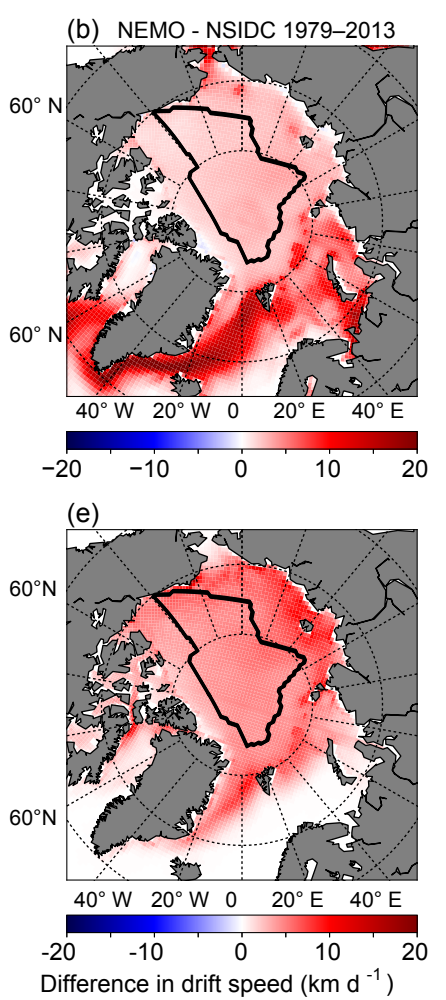

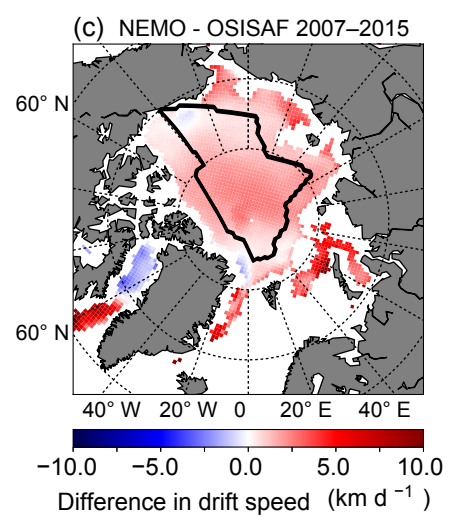

Difference in drift speed $\left(\mathrm{km} \mathrm{d}^{-1}\right)$

Figure 3. (a) Modelled (NEMO-LIM3.6) mean Arctic sea ice drift speed averaged over winter months (JFM, i.e. January-February-March) of the period 1979-2013. The direction of sea ice drift is represented by the vector arrows. (b) Difference in drift speed between NEMOLIM3.6 and the NSIDC dataset (Tschudi et al., 2016) averaged over winter months of the period 1979-2013. (c) Difference in drift speed between NEMO-LIM3.6 and OSI SAF averaged over winter months of the period 2007-2015. (d), (e) Same as (a), (b) respectively for summer months (JAS, i.e. July-August-September). OSI SAF drift data are not available in summer. The black polygon marks the SCICEX box.

Drift, are reasonably well represented by the model (Figs. 3a and $3 d$ ).

\subsection{How does sea ice drift relate to ice strength?}

The relationships between sea ice drift speed and strength can be quantified via the relationships between drift speed and concentration on the one hand and drift speed and thickness on the other hand. In this study, we analyse these relationships in terms of mean seasonal cycles. The linear relationship between drift speed and concentration is clear for both the model and the observations when concentration is relatively low (i.e. in summer): the lower the concentration, the higher the drift speed, with slopes significantly different from zero at the $5 \%$ level (Fig. 4a). The modelled driftconcentration slope is weaker than the observed ones (using IABP for drift speed) mainly due to too low mean modelled sea ice concentration in August and too high mean modelled drift speed in March and April. The modelled driftconcentration relationship is in better agreement with the observed IABP/OSI SAF pair (slope ratio $s_{A}=0.5$ and normalized distance $\epsilon_{A}=3.7 \%$ ) compared to IABP/Bootstrap $\left(s_{A}=0.3\right.$ and $\left.\epsilon_{A}=4.2 \%\right)$.
The relationship between drift speed and thickness shows a similar general pattern as the drift-concentration relationship with higher drift speed for lower thickness, with significant slopes at the $5 \%$ level (Fig. 4b). However, the drift-thickness relationship is more complex - with a hysteresis loop for NEMO-LIM3.6, the IABP/submarines pair and the IABP/PIOMAS pair. From May to September, during the melting season, sea ice thickness decreases and drift speed increases. Then, from September to March, drift speed decreases and thickness increases. The behaviour is slightly different between the model and observations, with a clearer linear relationship from May to September for observations, but the general shape of the scatter plot is similar. The drift-thickness slope ratio is higher (hence better) with the IABP/submarines pair $\left(s_{h}=0.6\right)$ compared to the IABP/PIOMAS pair $\left(s_{h}=0.5\right)$, while the drift-thickness normalized distance is lower (hence better) with the IABP/PIOMAS pair $\left(\epsilon_{h}=3.9 \%\right)$ compared to IABP/submarines $\left(\epsilon_{h}=6.0 \%\right)$. For both the model and observations, for a given thickness, the drift speed can take two values depending on the season: a high value in sum- 

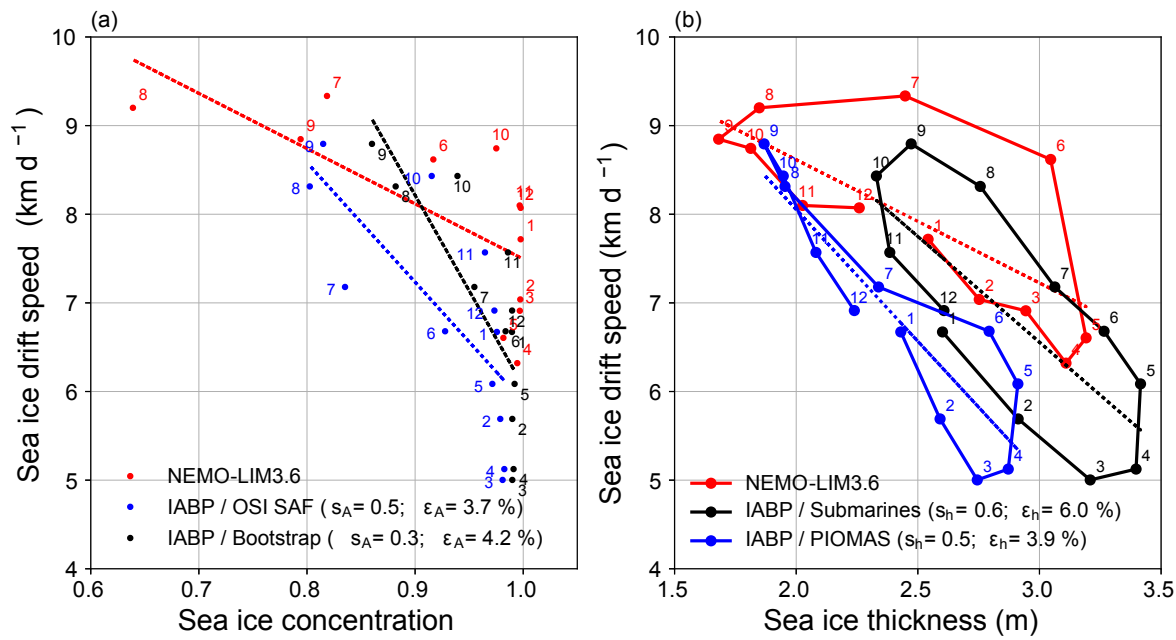

Figure 4. Scatter plots of modelled (NEMO-LIM3.6) and observed monthly mean sea ice drift speed against (a) concentration and (b) thickness temporally averaged over the period 1979-2013 (except for submarine observations that span 1975-2000) and spatially averaged over the SCICEX box. Numbers denote months. Dotted lines show linear regressions. Sources for observations and reanalysis: IABP for drift speed, OSI SAF and Bootstrap for concentration, submarines and PIOMAS for thickness. Slope ratios and normalized distances between NEMO-LIM3.6 and the different observation datasets are shown in brackets in the legends.

mer when sea ice melts and a low value in winter when sea ice forms and grows.

While the anticorrelation between drift speed and thickness is clearly physical in winter when concentration is high, this anticorrelation is probably only statistical in summer when concentration is low (Olason and Notz, 2014). To assess the performance of the modelled drift-thickness relationship against the observed one, we also computed our metrics over winter months only (November-March). By doing this, we find that the slope ratio is lower with both the IABP/submarines $\left(s_{h}=0.5\right)$ and IABP/PIOMAS $\left(s_{h}=0.4\right)$ pairs compared to the same computation over the whole year. In terms of normalized distance, results improve with the IABP/submarines pair $\left(\epsilon_{h}=5.0 \%\right)$ and deteriorate with the IABP/PIOMAS pair $\left(\epsilon_{h}=4.3 \%\right)$. Therefore, we do not think that computing our metrics over specific time periods allows a better understanding of the processes at play between drift speed and thickness.

The analysis of drift-concentration and drift-thickness relationships demonstrates that NEMO-LIM3.6 captures reasonably well drift-strength relationships on seasonal timescales. Note that relating drift speed to concentration and thickness for every month of the time series (instead of multi-year monthly means) also gives similar slopes with slightly lower model performance $\left(s_{A}=0.5\right.$ and $\epsilon_{A}=6.6 \%$ with the IABP/OSI SAF pair; $s_{h}=0.5$ and $\epsilon_{h}=7.8 \%$ with the IABP/PIOMAS pair).

\subsection{Sensitivity to changes in ice strength}

The previous scatter plots (Fig. 4) are valuable to provide insight regarding the relationships between sea ice dynamics and strength (concentration and thickness), but they do not quantify the impact of a change in sea ice strength on the resulting ice thickness and drift speed. In order to do this, we perform experiments in which we vary $P^{*}$ in Eq. (1), as described in Sect. 2.1.

Varying $P^{*}$ leads to tiny differences in mean sea ice concentration (not shown) but has a significant impact on sea ice thickness and drift speed (Fig. 5). For higher values of $P^{*}$, i.e. larger ice strength, the mean sea ice thickness is lower throughout the whole year (Fig. 5a) and the mean drift speed is lower in winter and spring and higher during summer and fall (Fig. 5b).

Increasing ice strength via the $P^{*}$ parameter leads to lower thickness values (Fig. 5a). A more careful spatial analysis allows us to see that the lower ice thickness with higher $P^{*}$ appears everywhere in the Arctic and during all months of the year, with the most visible differences occurring north of Greenland and the Canadian Archipelago - where ice is the thickest (Fig. 6). In the experiments with larger (lower) $P^{*}$, the mean ice thickness is lower (higher) due to lower (higher) deformation rates (Fig. 7a) and less (more) ice piling up (Fig. 6); this is similar to the finding of Steele et al. (1997). Deformation rates are computed from strain rate divergence and shear following Eq. (5) from Spreen et al. (2017). However, deformation rates from the experiment with $P^{*}=100 \mathrm{kN} \mathrm{m}^{-2}$ are relatively high compared to other experiments, especially in winter (Fig. 7a), despite the relatively low thickness arising from this experiment (Fig. 5a). The net ice production resulting from this experiment, which combines all sea ice mass balance processes described in Rousset et al. (2015), is 1.5 times lower than the four other experiments on average, which all provide a very similar sea- 

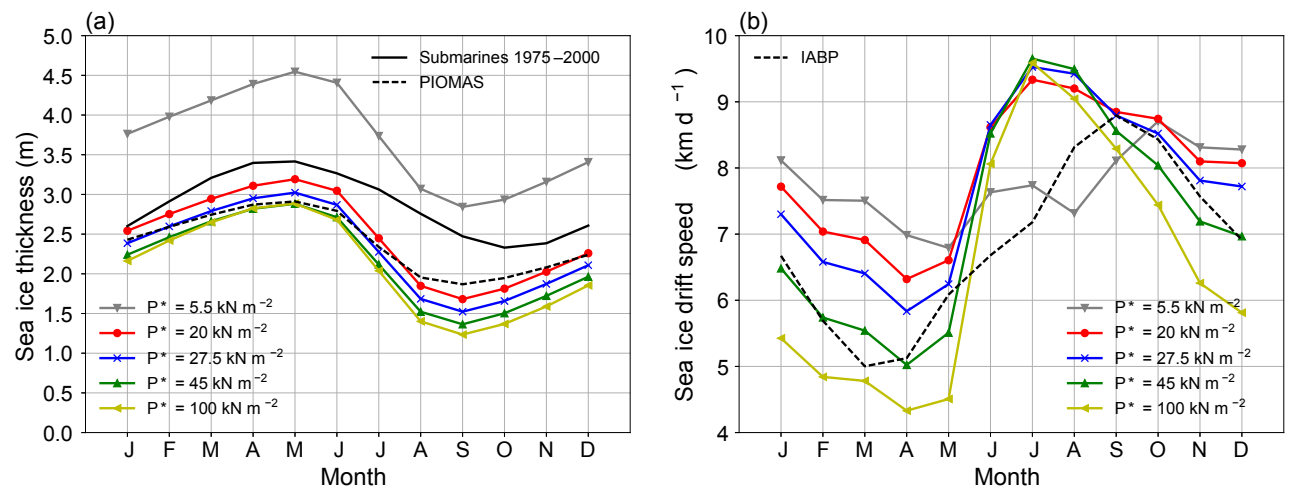

Figure 5. Modelled (NEMO-LIM3.6) monthly mean seasonal cycles of sea ice (a) thickness and (b) drift speed temporally averaged over the period 1979-2013 and spatially averaged over the SCICEX box for five different $P^{*}$ values (see Eq. 1). Observations and reanalysis are represented as black lines - submarine observations, spanning 1975-2000, and PIOMAS for thickness in (a) and IABP for drift speed in (b).

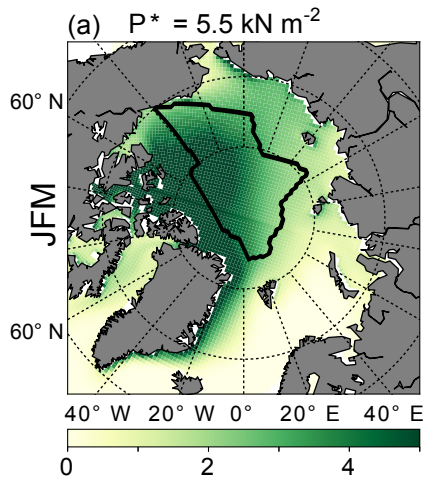

(d)

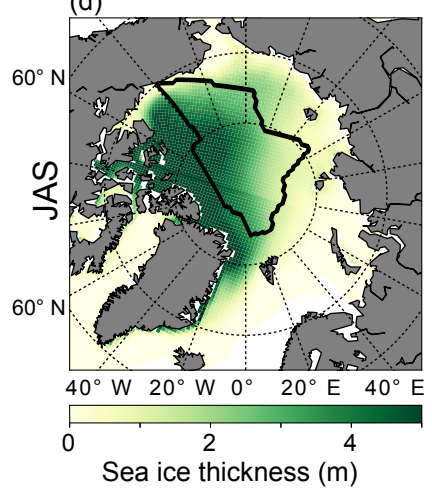

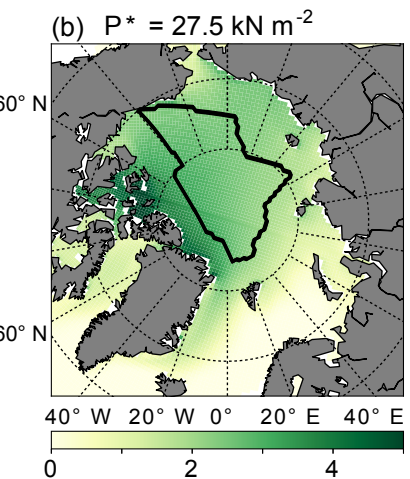

(e)

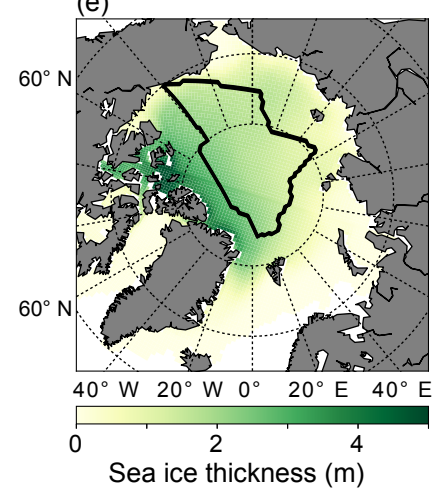

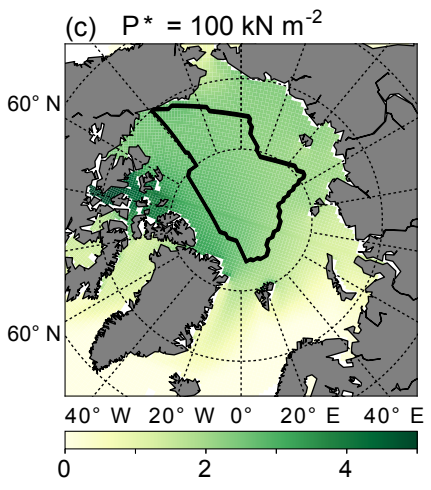

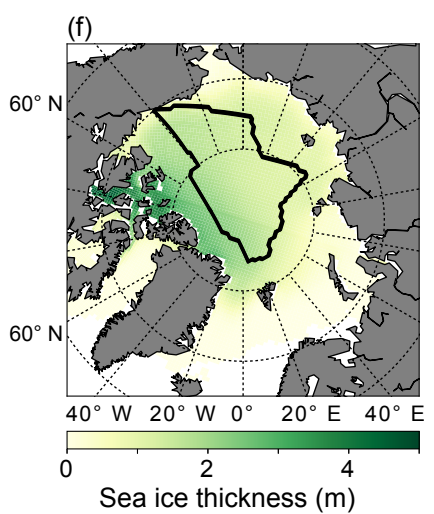

Figure 6. Modelled (NEMO-LIM3.6) mean Arctic sea ice thickness averaged over winter months (JFM, i.e. January-February-March) of the period 1979-2013 for (a) $P^{*}=5.5 \mathrm{kN} \mathrm{m}^{-2}$, (b) $P^{*}=27.5 \mathrm{kN} \mathrm{m}^{-2}$, (c) $P^{*}=100 \mathrm{kN} \mathrm{m}^{-2}$. Panels (d), (e) and (f) are the same as (a), (b) and (c) respectively for summer months (JAS, i.e. July-August-September). The black polygon marks the SCICEX box.

sonal cycle (Fig. 7b). Therefore, relatively high deformation rates with $P^{*}=100 \mathrm{kN} \mathrm{m}^{-2}$ are compensated by relatively low net ice production, which provides low ice thickness. Table 2 provides a summary of mean ice thickness, drift speed, deformation rates and net ice production averaged over the whole period and over the SCICEX box.

The experiments with higher $P^{*}$ also provide a more uniform sea ice thickness distribution resulting from a higher ice strength. Figure 8 shows the distribution of ice-covered grid cells in each thickness bin for both winter and summer months: the higher the ice strength (higher $P^{*}$ ), the higher the number of grid cells in the modal class $(2.5-3 \mathrm{~m}$ in winter and $1.5-2.5 \mathrm{~m}$ in summer), and the more uniform (i.e. peaked) the thickness distribution.

Higher sea ice drift speed with higher ice strength from June to August, except for $P^{*}=100 \mathrm{kN} \mathrm{m}^{-2}$ (Fig. 5b), prob- 

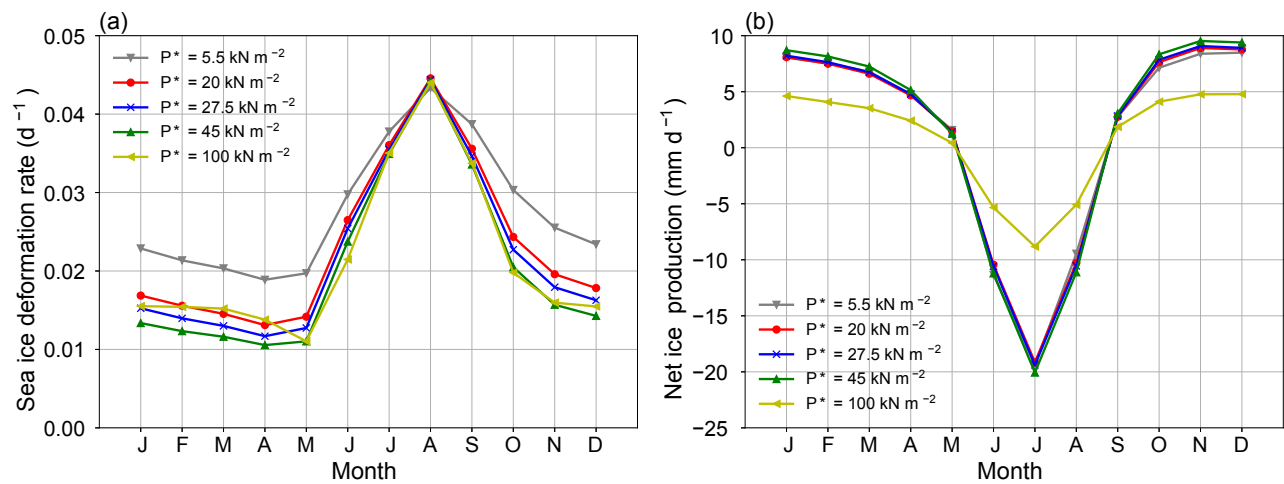

Figure 7. Modelled (NEMO-LIM3.6) monthly mean seasonal cycles of (a) sea ice deformation rate and (b) net ice production temporally averaged over the period 1979-2013 and spatially averaged over the SCICEX box for five different $P^{*}$ values.
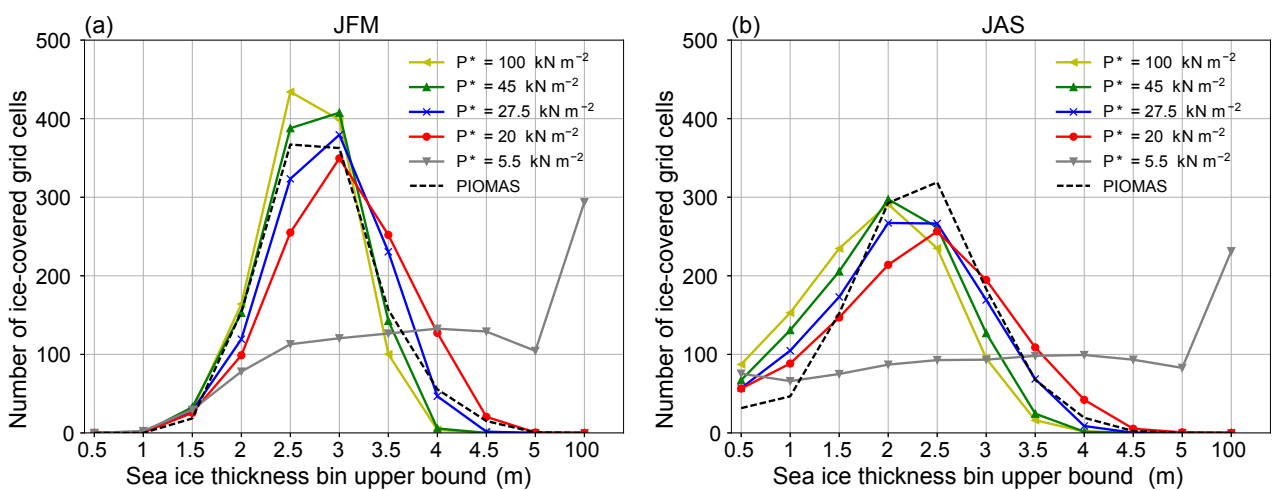

Figure 8. Number of ice-covered grid cells in each thickness bin temporally averaged over 1979-2013 and spatially averaged over the SCICEX box for both (a) winter (JFM, i.e. January-February-March) and (b) summer (JAS, i.e. July-August-September). Results are shown for NEMO-LIM3.6 (five different $P^{*}$ values) and for PIOMAS reanalysis interpolated onto the eORCA1 grid. The $x$ axis shows the upper bound of each thickness bin.

Table 2. Mean sea ice thickness $h$, drift speed $D$, deformation rates $d_{\mathrm{r}}$ and net ice production $p_{\mathrm{i}}$ temporally averaged over the period 1979-2013 and spatially averaged over the SCICEX box for the five $P^{*}$ experiments.

\begin{tabular}{lrrrr}
\hline$P^{*}\left(\mathrm{kN} \mathrm{m}^{-2}\right)$ & $h(\mathrm{~m})$ & $D\left(\mathrm{~km} \mathrm{~d}^{-1}\right)$ & $d_{\mathrm{r}}\left(\mathrm{d}^{-1}\right)$ & $p_{\mathrm{i}}\left(\mathrm{mm} \mathrm{d}^{-1}\right)$ \\
\hline 5.5 & 3.70 & 7.75 & 0.0277 & 1.27 \\
20 & 2.47 & 7.96 & 0.0232 & 1.38 \\
27.5 & 2.31 & 7.73 & 0.0219 & 1.41 \\
45 & 2.16 & 7.23 & 0.0205 & 1.53 \\
100 & 2.09 & 6.53 & 0.0214 & 0.95 \\
\hline
\end{tabular}

ably stems from the fact that for higher strength, ice thickness is lower at the beginning of the summer (Fig. 5a), leading to higher drift speed values. The modelled drift speed is closer to observations with $P^{*}=5.5 \mathrm{kN} \mathrm{m}^{-2}$ in June and July; $P^{*}=27.5 \mathrm{kN} \mathrm{m}^{-2}$ in May and from September to November; $P^{*}=45 \mathrm{kN} \mathrm{m}^{-2}$ from December to February and in April; $P^{*}=100 \mathrm{kN} \mathrm{m}^{-2}$ in March. Therefore, there is no single $P^{*}$ value that provides a best fit to observed drift speed.
Figure 9 shows the drift-concentration and drift-thickness relationships for the model with different $P^{*}$ values as well as observations in terms of mean seasonal cycle averaged over the period 1979-2013 and over the SCICEX box. All model simulations but one $\left(P^{*}=5.5 \mathrm{kN} \mathrm{m}^{-2}\right)$ provide coherent relationships with significant slopes at the $5 \%$ level, i.e. a decreasing drift speed with increasing concentration and thickness as well as a hysteresis loop for the drift-thickness relationship. It is also clearly apparent from Fig. 9b that a higher $P^{*}$ parameter value leads to lower thickness and a higher amplitude of the seasonal cycle of drift speed.

By plotting each of our metrics against $P^{*}$, we show that $P^{*}=45 \mathrm{kN} \mathrm{m}^{-2}$ is the best option in terms of driftconcentration slope ratio $\left(s_{A}=0.7\right.$ with IABP/OSI SAF and $s_{A}=0.5$ with IABP/Bootstrap, Fig. 10a) and normalized distance $\left(\epsilon_{A}=2.5 \%\right.$ with IABP/OSI SAF and $\epsilon_{A}=3.1 \%$ with IABP/Bootstrap, Fig. 10c) over the whole year. $P^{*}=45$ and $100 \mathrm{kN} \mathrm{m}^{-2}$ are the best fits for the drift-thickness slope ratio $\left(s_{h}=0.8\right.$ with IABP/submarines and $s_{h}=0.7$ with IABP/PIOMAS, Fig. 10b). The drift-thickness normalized distance is the smallest using $P^{*}=20 \mathrm{kN} \mathrm{m}^{-2}$ with 

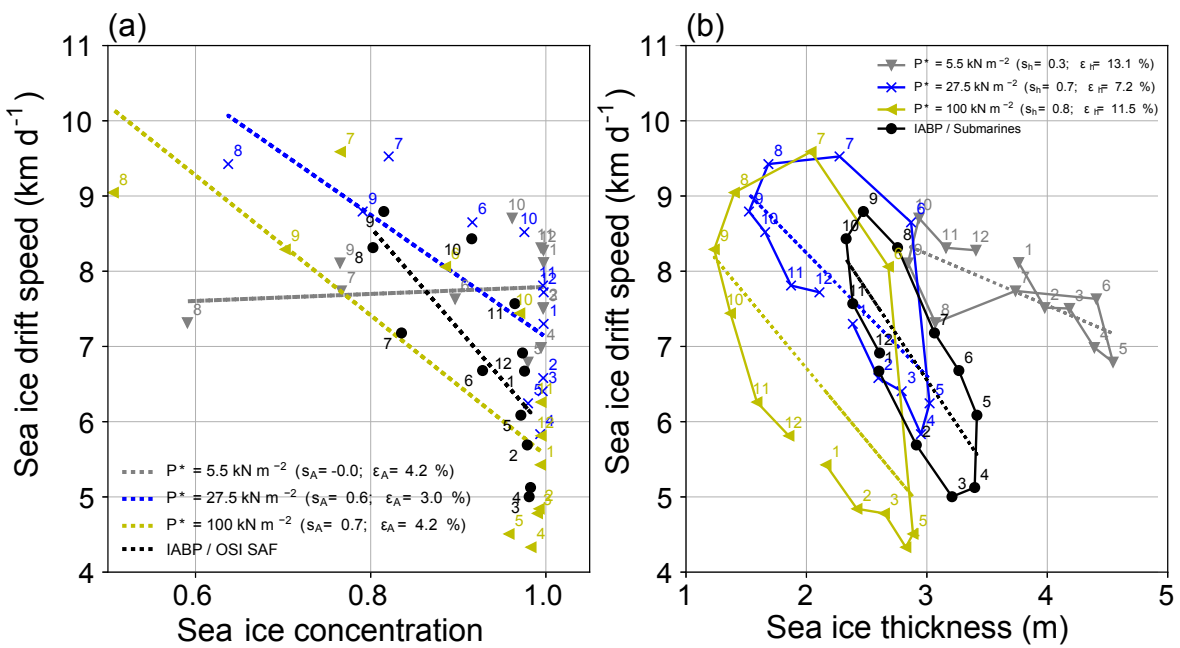

Figure 9. Scatter plots of modelled (NEMO-LIM3.6) monthly mean sea ice drift speed against sea ice (a) concentration and (b) thickness temporally averaged over the period 1979-2013 and spatially averaged over the SCICEX box for the different $P^{*}$ values (only three values for readability). Numbers denote months. Observations are represented in black. Dotted lines show linear regressions. Slope ratios and normalized distances between NEMO-LIM3.6 and the different observation datasets are shown in brackets in the legend.

IABP/submarines $\left(\epsilon_{h}=6.0 \%\right)$ and $P^{*}=27.5 \mathrm{kN} \mathrm{m}^{-2}$ with IABP/PIOMAS $\left(\epsilon_{h}=3.2 \%\right)$ (Fig. 10d). Results are qualitatively similar for the drift-concentration slope ratio over summer months (Fig. 10a) and the drift-thickness slope ratio over winter months (Fig. 10b) compared to these ratios computed over the whole year. $P^{*}=5.5 \mathrm{kN} \mathrm{m}^{-2}$ is the best option for the drift-concentration normalized distance during summer (Fig. 10c), while $P^{*}=45 \mathrm{kN} \mathrm{m}^{-2}$ is the best fit for the drift-thickness normalized distance in winter (Fig. 10d). Although $P^{*}=45 \mathrm{kN} \mathrm{m}^{-2}$ appears as a good candidate overall, it is not highly superior to other $P^{*}$ values and not the best option in terms of reproducing the observed mean seasonal cycles of thickness and drift speed (Fig. 5).

\section{Discussion}

\subsection{Novelties of the present study}

The main novelty of the present study is the in-depth analysis of the relationships between Arctic sea ice drift and sea ice strength (concentration and thickness) via an extension of the work carried out by Olason and Notz (2014) and a series of model sensitivity experiments in which the sea ice strength is varied. Rampal et al. (2011) mention these relationships as an important element of Arctic sea ice processes, and other studies analyse relationships between some elements of the system (Spreen et al., 2011; Kwok et al., 2013; Langehaug et al., 2013; Olason and Notz, 2014), but none of these studies quantifies the magnitude of drift-strength relationships in detail. Here we address this issue using NEMO-LIM3.6 at $1^{\circ}$ resolution with several process-based diagnostics and met- rics as well as sensitivity experiments with different values of initial sea ice strength.

The drift-concentration and drift-thickness diagnostics and metrics used here are based on the work of Olason and Notz (2014). They analyse the relationships between the three variables using different observational datasets within the SCICEX box. On seasonal timescales, they find that sea ice concentration controls sea ice drift speed in summer (when concentration is relatively low) and sea ice thickness is the main driver in winter (when concentration is relatively high). In our analysis, we include model results and we also find that drift speed is anti-correlated to concentration during summer months in the same SCICEX box (Fig. 4a). We also find that drift speed is anti-correlated to thickness not only during winter months but also during summer (with a clearer relationship for the observations compared to the model, Fig. 4b). However, the drift-thickness relationship has less physical meaning in summer when concentration is high (Olason and Notz, 2014) and the impact of varying $P^{*}$ on drift speed is lower in summer. In our study, we do not normalize sea ice drift speed by wind friction speed as in Olason and Notz (2014) because the same relationship is found with and without normalization. In sum, we find that on seasonal timescales drift speed is strongly influenced by both thickness and concentration.

There are some similarities between the results arising from our sensitivity experiments and the findings from Steele et al. (1997), which use a $40 \mathrm{~km}$ resolution sea ice model based on Hibler (1979) over 7 model years. They explain that, as $P^{*}$ decreases (for $P^{*}<30-40 \mathrm{kN} \mathrm{m}^{-2}$ ), internal stress gradient decreases and mean ice motion increases (with ice nearly in free drift for $P^{*}=5.5 \mathrm{kN} \mathrm{m}^{-2}$ ), which 

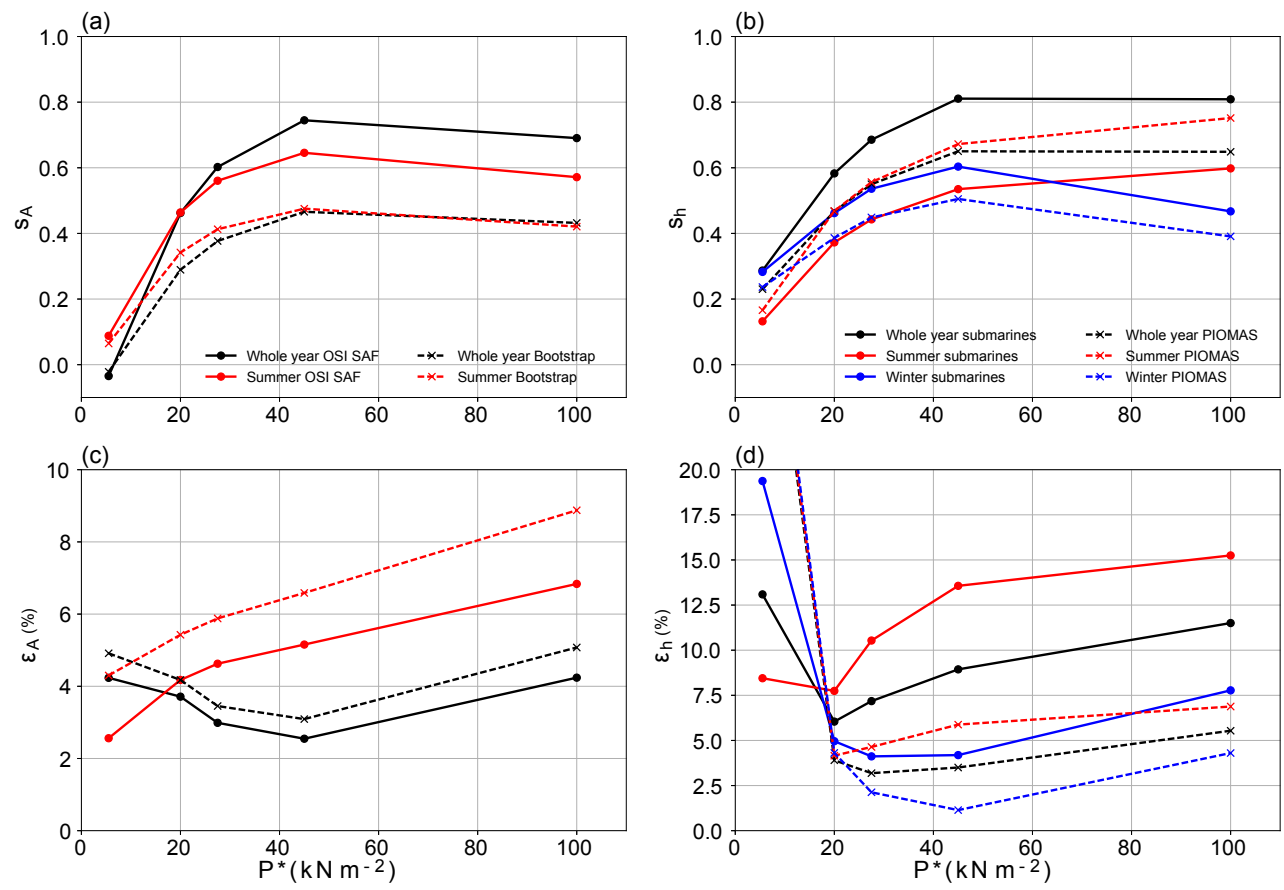

Figure 10. (a) Drift-concentration slope ratio $s_{A}$, (b) drift-thickness slope ratio $s_{h}$, (c) drift-concentration normalized distance $\epsilon_{A}$ and (d) drift-thickness normalized distance $\epsilon_{h}$ as a function of ice strength parameter $P^{*}$. Black lines show the average over the whole year, red lines over summer (May-September), and blue lines over winter (November-March). In (a) and (c), observed sea ice concentration is retrieved from OSI SAF (solid lines) and Bootstrap (dashed lines). In (b) and (d), sea ice thickness comes from submarines (solid lines) and PIOMAS (dashed lines). In all sub-figures, sea ice drift speed is from IABP. Drift-concentration metrics are not shown for winter in (a) and (c) as concentration is high and almost constant at that time of the year (Fig. 4a).

leads to higher ice thickness. However, for $P^{*}>55 \mathrm{kN} \mathrm{m}^{-2}$, ice thickness slightly increases with increasing $P^{*}$ in Steele et al. (1997) due to the progressive locking of sea ice (the ice motion ceases), providing an ice thickness mainly determined by equilibrium thermodynamics. We do not observe this nonlinearity in our sensitivity experiments as ice thickness continues decreasing with increasing $P^{*}$ for $P^{*} \geq$ $45 \mathrm{kN} \mathrm{m}^{-2}$ (Fig. 5a). Several reasons could explain this difference between Steele et al. (1997) and our study, including differences in model physics (e.g. ice thickness distribution included in our model), model parameters (e.g. grid resolution, time step), experimental setup (e.g. model years, forcing) and averaging domain. However, in our experiments, ice thickness from February to June is very similar between $P^{*}=45 \mathrm{kN} \mathrm{m}^{-2}$ and $P^{*}=100 \mathrm{kN} \mathrm{m}^{-2}$ (Fig. 5a), and deformation rates with $P^{*}=100 \mathrm{kN} \mathrm{m}^{-2}$ are relatively high (Fig. 7a). Therefore, this nonlinearity may occur for $P^{*}>$ $100 \mathrm{kN} \mathrm{m}^{-2}$.

Our study can also be used to identify which $P^{*}$ values yield results close to reference products (observations and reanalyses). We show that $P^{*}=45 \mathrm{kN} \mathrm{m}^{-2}$ is a good candidate in terms of the metrics we use (Fig. 10). However, this value is not highly superior to other $P^{*}$ values. Our findings also suggest that the best match is strongly dependent upon the month of the year. For sea ice thickness, the amplitude of the modelled seasonal cycle is higher than the ones derived from submarine observations and PIOMAS reanalysis, so that all $P^{*}$ values ranging from 5.5 to $100 \mathrm{kN} \mathrm{m}^{-2}$ could be used depending on the month (Fig. 5a). For drift speed, the highest values of $P^{*}\left(45\right.$ and $100 \mathrm{kN} \mathrm{m}^{-2}$ ) better match observations in winter, and the lowest value $\left(5.5 \mathrm{kN} \mathrm{m}^{-2}\right)$ is more suitable in summer (Fig. 5b). In agreement with Massonnet et al. (2014), we do not recommend a specific value of $P^{*}$, since the optimal value for that parameter is dependent on many factors (resolution, atmospheric forcing, values chosen for other parameters, initial conditions, model). We still recommend excluding the lowest value $\left(P^{*}=5.5 \mathrm{kN} \mathrm{m}^{-2}\right)$ from the possibilities due to a weaker representation of the drift-concentration and drift-thickness relationships (Fig. 9). This shows the limitations of the parameterization from Hibler (1979) and could support the use of new sea ice rheologies, such as the elasto-brittle rheology (Girard et al., 2011; Dansereau et al., 2016).

\subsection{Complexity of drift-strength relationships}

The potential positive feedback between sea ice drift and strength that is described in Rampal et al. (2011) proposes that an initial decrease in sea ice concentration or thickness leads to a decrease in sea ice strength and internal stress. This 
results in larger deformation and enhanced drift speed. According to Rampal et al. (2011), this would lead to an increased export of sea ice out of the Arctic Basin. This finally would lead to further decreases in sea ice concentration and thickness. However, observations do not show an increase in ice export (Döscher et al., 2014), while there is a clear decrease in concentration and thickness (Stroeve et al., 2012; Vaughan et al., 2013) and increase in drift speed (Spreen et al., 2011). Furthermore, our study shows that, even if this positive feedback exists, it is more complex than Rampal et al. (2011) suggest, for two main reasons.

The first complication is the fact that a change in export of sea ice is not only a cause but also a consequence of changes in concentration and thickness. The volume export is the product of sea ice drift speed, concentration and thickness. Therefore, a decrease in concentration or thickness will both emphasize the positive feedback by increasing drift speed and the resulting export of sea ice, and reduce its magnitude by directly decreasing export of sea ice. This will balance the resulting sea ice export. We compute sea ice export at Fram Strait from sea ice drift speed, thickness (which takes into account concentration, since our thickness is the sea ice volume per area) and transect length at two different latitudes (76 and $80^{\circ} \mathrm{N}$ ) following Spreen et al. (2009). From 1979 to 2013, the volume flux modelled by NEMO-LIM3.6 decreases with a negative trend of $1.8 \mathrm{~km}^{3} \mathrm{~d}^{-1}$ decade $^{-1}$ in the control simulation $\left(P^{*}=20 \mathrm{kN} \mathrm{m}^{-2}\right)$ but interannual variations are very large, especially at the southern transect $\left(76^{\circ} \mathrm{N}\right)$. Increasing ice strength (by increasing $P^{*}$ ) results in a decreasing volume flux at Fram Strait mainly due to the lower thickness. Therefore, in our model the direct effect of decreasing concentration and thickness is more important than the impact of increasing drift speed on the export at Fram Strait.

The second source of complexity is the fact that sea ice thickness decreases with higher ice strength (Sect. 3.3). If the drift-strength feedback dominated in our $P^{*}$ experiments, ice thickness would be higher for higher ice strength (higher $P^{*}$ ), due to lower drift speed and export. However, ice thickness decreases with higher ice strength due to lower deformation (Figs. 5a and 7a). Thus, isolating the drift-strength feedback with a set of sensitivity experiments is difficult.

A previous study demonstrated the impact of increased ice strength using a coupled ice-ocean model to account for large-scale effects (Häkkinen and Mellor, 1992). They use both the classical Hibler parameterization for ice strength as well as a square dependence of ice strength on thickness for first-year sea ice following Overland and Pease (1988) and compare both approaches. They show that increased ice strength leads to thicker ice, which is different from what we find in this study (increased strength leads to thinner ice). However, Häkkinen and Mellor (1992) do not use an ITD scheme, which may explain the difference with our results. Some sea ice models that include an ITD scheme use $P$ scaling as $h^{3 / 2}$, since it is more physically realistic than $P$ scaling as $h$ (Rothrock, 1975). However, using such a scaling is less numerically stable (Lipscomb et al., 2007) and leads to poorer agreement with observations (Ungermann et al., 2017). According to Leppäranta (2011), the exact value of the thickness exponent remains an open question.

To test the impact of such a scaling on the resulting ice thickness and drift speed, we also performed sensitivity experiments in which we introduce an exponent $\lambda$ in the ice strength Eq. (1), varying between 0.5 and $2(\lambda=1$ corresponds to the original formulation of Hibler, 1979):

$$
P=P^{*} h^{\lambda} \exp [-C(1-A)] .
$$

These experiments are more complex than the $P^{*}$ experiments since they introduce a nonlinear dependence between ice strength $P$ and ice thickness $h$ but they provide insight into the understanding of the impact of a change in the ice strength parameterization. Overall, these experiments lead to similar conclusions as for the $P^{*}$ experiments: higher $\lambda$ leads to lower ice thickness, lower drift speed in winter and higher drift speed in summer, lower ice thickness heterogeneity, and a similar behaviour for drift-concentration and driftthickness relationships.

An additional element that has not been studied here and could increase the complexity of the drift-strength relationships is the interaction between the ocean-sea ice system and the atmosphere. In this analysis, we use an ocean-sea ice model forced by atmospheric reanalysis. A full coupling with the atmosphere could provide different results regarding drift-strength relationships. For example, Juricke and Jung (2014) find that the implementation of a stochastic sea ice strength parameterization leads to different responses in the coupled ECHAM6-FESOM model compared to the FESOM model forced by atmospheric fluxes generated by the coupled model. In the uncoupled simulation, the Arctic sea ice volume increases compared to a reference run without parameterization, while the volume remains largely unchanged in the coupled simulation. This suggests that a negative atmospheric feedback explains the differences between both coupled and uncoupled modes. Therefore, care needs to be taken when extrapolating results from forced simulations to coupled models. Specifically for our study, the effect of coupling on drift-strength relationships could be assessed by comparing our results to coupled simulations using NEMO-LIM3.6 (e.g. EC-Earth in the framework of CMIP6).

\subsection{Impact of domain choice}

In this study, we compute spatial means both over the SCICEX box, roughly corresponding to the central Arctic, and over a wider domain encompassing all grid cells north of $50^{\circ} \mathrm{N}$ with a concentration threshold $(A \geq 0.15)$. We prefer using the SCICEX box in our study because it produces much better agreement between the model and observations. The wider domain includes the large model biases occurring in the vicinity of the ice front and of straits, e.g. model overestimation of drift speed at Fram Strait (Fig. 3). 
The use of the wider domain produces results for driftconcentration and drift-thickness relationships that clearly diverge compared to observations due to the inclusion of coastal grid cells that have high model biases. Computing mean concentration, thickness and drift speed over the central Arctic (SCICEX box in our analysis) provides values that are much more consistent with observations and more representative of Arctic conditions.

Therefore, the comparison between our central and wide domains demonstrates the impact of domain choice, with generally better performance when using the central domain. A decomposition of the Arctic Ocean into sub-regions such as in Koenigk et al. (2016) would be a possible improvement compared to the use of a single wider domain.

\subsection{How can this methodology help in future model intercomparisons?}

The methodology proposed in this analysis, particularly the process-based diagnostics and metrics, can be used to assess the performance of other models against observational datasets, which will be an important component of SIMIP (Notz et al., 2016). It can be extended to models being forced by atmospheric reanalysis (such as the model used here) as well as fully coupled models, in order to provide a benchmark for further model intercomparison. In the framework of such a model intercomparison, the use of the process-based metrics that we developed (slope ratios and normalized distances) may be valuable for identifying which models fall within the observational range.

In this study, we only focus on one model resolution. Although some preliminary results show that a higher spatial resolution with NEMO-LIM3.6 provides a higher sea ice thickness, there is a need for a deeper analysis of the impact of model resolution. The methodology proposed fits quite well into the framework of the EU Horizon 2020 PRIMAVERA project (https://www.primavera-h2020.eu/), which aims at evaluating the effect of high resolution in global climate models.

Finally, this process-based analysis provides an alternative to classic model evaluations that only look at sea ice extent and thickness. It systematically highlights the links between sea ice dynamic and thermodynamic processes. Evaluating new sea ice rheologies using this methodology will provide a stronger test of model performance.

\section{Conclusions}

The relationships between sea ice drift speed and strength are well represented through the relationships between drift speed and concentration on the one hand, and drift speed and thickness on the other hand. In particular, the increasing drift speed with lower concentration and thickness is reproduced by the model. Different process-based metrics were devel- oped in the framework of this study and allow to test the performance of our model against observations and reanalyses. The drift-thickness relationship is marked by a hysteresis loop: two drift speed values are possible for a given thickness depending on the season, with a higher sea ice drift speed during the melting season and a lower value during the growing season. This indicates that further investigation is needed to identify other potential factors that control the drift speed.

Sensitivity experiments show that higher initial ice strength leads to lower ice thickness. This is due to lower deformation rates that prevents ice piling up, especially north of Greenland and the Canadian Archipelago. In the case of the highest strength experiment used here, net ice production is relatively low, which compensates for relatively high deformation rates. These experiments also show that $P^{*}=45 \mathrm{kN} \mathrm{m}^{-2}$ is a good candidate in terms of driftconcentration and drift-thickness relationships. However, this value is not highly superior to other $P^{*}$ values and the best $P^{*}$ option for reproducing the observed mean seasonal cycles of drift speed and thickness depends on the month of the year. Therefore, we do not recommend one single $P^{*}$ value. We suggest that other rheologies might be more appropriate.

Finally, this study shows that the relationships between sea ice dynamics and state are complex and cannot be summarized by a simple feedback loop. The diagnostics and metrics proposed in this study that relate drift speed to concentration and thickness are necessary conditions for representing the drift-strength relationships, but they are not sufficient. Sensitivity experiments in which sea ice strength is varied are also essential for gaining insight into these relationships. In this analysis, we use one resolution of one model with an atmospherically forced mode. A multi-model assessment using different model resolutions, e.g. in the framework of the EU Horizon 2020 PRIMAVERA project, will provide further insight into the relationships between sea ice dynamics and state.

Code availability. All codes for computing and plotting the results of this article are written in Python programming language and are available upon request.

Author contributions. DD, FM and TF designed the experimental study. FM and AB performed the model simulations. DD collected the observational datasets, developed the diagnostics and metrics, analysed the results and produced the figures. NFT and OL provided substantial feedback to the analysis. DD prepared the manuscript with contributions from all co-authors.

Competing interests. The authors declare that they have no conflict of interest. 
Acknowledgements. David Docquier and Antoine Barthélemy work on the PRIMAVERA project (PRocess-based climate sIMulation: AdVances in high-resolution modelling and European climate Risk Assessment), which is funded by the European Commission's Horizon 2020 programme, grant agreement no. 641727. François Massonnet is funded by the Belgian Fonds National de la Recherche Scientifique (FNRS) and was funded by the Ministerio de Economía, Industria y Competitividad (MINECO). Neil F. Tandon is supported by the Canadian Sea Ice and Snow Evolution (CanSISE) Network. Olivier Lecomte is a research assistant within the Belgian FNRS. The present research benefited from computational resources made available on the Tier-1 supercomputer of the Fédération Wallonie-Bruxelles, infrastructure funded by the Walloon Region under the grant agreement no. 1117545. Computational resources have also been provided by the Consortium des Équipements de Calcul Intensif (CÉCI), funded by the Fonds de la Recherche Scientifique de Belgique (F.R.S.-FNRS) under grant no. 2.5020.11. We would like to thank Hugues Goosse, Martin Vancoppenolle, Jonathan Raulier and Véronique Dansereau for their very helpful comments regarding this study. We also acknowledge Pierre-Yves Barriat for his help in using computing resources at UCL and Damien François for his advice in improving Python scripts. Finally, we thank the editor Dirk Notz and the two anonymous reviewers for helping to improve the original paper.

Edited by: D. Notz

Reviewed by: two anonymous referees

\section{References}

Comiso, J.: Bootstrap Sea Ice Concentrations from Nimbus-7 SMMR and DMSP SSM/I-SSMIS, Version 2, available at: https://doi.org/10.5067/J6JQLS9EJ5HU (last access: 11 January 2017), 2015.

Comiso, J. C.: Characteristics of Arctic winter sea ice from satellite multispectral microwave observations, J. Geophys. Res., 91, 975-994, 1986.

Comiso, J. C., Cavalieri, D. J., Parkinson, C. L., and Gloersen, P.: Passive microwave algorithms for sea ice concentration: A comparison of two techniques, Remote Sens. Environ., 60, 357-384, 1997.

Dansereau, V., Weiss, J., Saramito, P., and Lattes, P.: A Maxwell elasto-brittle rheology for sea ice modelling, The Cryosphere, 10, 1339-1359, https://doi.org/10.5194/tc-10-1339-2016, 2016.

Döscher, R., Vihma, T., and Maksimovich, E.: Recent advances in understanding the Arctic climate system state and change from a sea ice perspective: a review, Atmos. Chem. Phys., 14, 1357113600, https://doi.org/10.5194/acp-14-13571-2014, 2014.

Dupont, F., Higginson, S., Bourdallé-Badie, R., Lu, Y., Roy, F., Smith, G. C., Lemieux, J.-F., Garric, G., and Davidson, F.: A high-resolution ocean and sea-ice modelling system for the Arctic and North Atlantic oceans, Geosci. Model Dev., 8, 15771594, https://doi.org/10.5194/gmd-8-1577-2015, 2015.

Dussin, R., Barnier, B., Brodeau, L., and Molines, J. M.: The making of the Drakkar Forcing Set DFS5, Tech. rep., Multiscale Ocean Modelling Team, Laboratoire de Glaciologie et Géophysique de l'Environnement, Grenoble, France, available at: https://www.drakkar-ocean.eu/forcing-the-ocean (last access: 13 June 2017), 2016.

EUMETSAT OSI SAF: Global sea ice concentration reprocessing dataset 1978-2015 (v1.2), available at: http://www.osi-saf.org/ (last access: 10 March 2016), 2015a.

EUMETSAT OSI SAF: Low resolution sea ice drift product, available at: http://www.osi-saf.org/ (last access: 16 August 2016), 2015b.

Feltham, D. L.: Sea Ice Rheology, Annu. Rev. Fluid Mech., 40, 91112, https://doi.org/10.1146/annurev.fluid.40.111406.102151, 2008.

Gimbert, F., Jourdain, N. C., Marsan, D., Weiss, J., and Barnier, B.: Recent mechanical weakening of the Arctic sea ice cover as revealed from larger inertial oscillations, Geophys. Res. Lett., 117, C00J12, https://doi.org/10.1029/2011JC007633, 2012.

Girard, L., Bouillon, S., Weiss, J., Amitrano, D., Fichefet, T., and Legat, V.: A new modeling framework for sea-ice mechanics based on elasto-brittle rheology, Ann. Glaciol., 52, 123-132, 2011.

Haarsma, R. J., Roberts, M. J., Vidale, P. L., Senior, C. A., Bellucci, A., Bao, Q., Chang, P., Corti, S., Fuckar, N. S., Guemas, V., von Hardenberg, J., Hazeleger, W., Kodama, C., Koenigk, T., Leung, L. R., Lu, J., Luo, J.-J., Mao, J., Mizielinski, M. S., Mizuta, R., Nobre, P., Satoh, M., Scoccimarro, E., Semmler, T., Small, J., and von Storch, J.-S.: High Resolution Model Intercomparison Project (HighResMIP v1.0) for CMIP6, Geosci. Model Dev., 9, 4185-4208, https://doi.org/10.5194/gmd-9-4185-2016, 2016.

Häkkinen, S. and Mellor, G. L.: Modeling the seasonal variability of a coupled Arctic ice-ocean system, J. Geophys. Res., 97, 2028520304, https://doi.org/10.1029/92JC02037, 1992.

Häkkinen, S., Proshutinsky, A., and Ashik, I.: Sea ice drift in the Arctic since the 1950s, Geophys. Res. Lett., 35, L19704, https://doi.org/10.1029/2008GL034791, 2008.

Hibler, W. D.: A Dynamic Thermodynamic Sea Ice Model, J. Phys. Oceanogr., 9, 815-846, 1979.

Hibler, W. D. and Walsh, J. E.: On modeling seasonal and interannual fluctuations of Arctic sea ice, J. Phys. Oceanogr., 12, 15141523, 1982.

Ivanova, N., Pedersen, L. T., Tonboe, R. T., Kern, S., Heygster, G., Lavergne, T., Sørensen, A., Saldo, R., Dybkjær, G., Brucker, L., and Shokr, M.: Inter-comparison and evaluation of sea ice algorithms: towards further identification of challenges and optimal approach using passive microwave observations, The Cryosphere, 9, 1797-1817, https://doi.org/10.5194/tc9-1797-2015, 2015.

Juricke, S. and Jung, T.: Influence of stochastic sea ice parametrization on climate and the role of atmosphere-sea ice-ocean interaction, Philos. Trans. A Math. Phys. Eng. Sci., 28, 372, https://doi.org/10.1098/rsta.2013.0283, 2014.

Juricke, S., Lemke, P., Timmerman, R., and Rackow, T.: Effects of stochastic ice strength perturbation on Arctic finite element sea ice modeling, J. Climate, 26, 3785-3802, https://doi.org/10.1175/JCLI-D-12-00388.1, 2013.

Koenigk, T., Caian, M., Nikulin, G., and Schimanke, S.: Regional Arctic sea ice variations as predictor for winter climate conditions, Clim. Dynam., 46, 317-337, https://doi.org/10.1007/s00382-015-2586-1, 2016. 
Kreyscher, M., Harder, M., and Lemke, P.: First results of the SeaIce Model Intercomparison Project (SIMIP), Ann. Glaciol., 25, 8-11, https://doi.org/10.1017/S0260305500013719, 1997.

Krumpen, T., Gerdes, R., Haas, C., Hendricks, S., Herber, A., Selyuzhenok, V., Smedsrud, L., and Spreen, G.: Recent summer sea ice thickness surveys in Fram Strait and associated ice volume fluxes, The Cryosphere, 10, 523-534, https://doi.org/10.5194/tc10-523-2016, 2016.

Kwok, R.: Outflow of Arctic Ocean Sea Ice into the Greenland and Barents Seas: 1979-2007, J. Climate, 22, 2438-2457, https://doi.org/10.1175/2008JCLI2819.1, 2009.

Kwok, R., Cunningham, G. F., Wensnahan, M., Rigor, I., Zwally, H. J., and Yi, D.: Thinning and volume loss of the Arctic Ocean sea ice cover: 2003-2008, J. Geophys. Res., 114, C07005, https://doi.org/10.1029/2009JC005312, 2009.

Kwok, R., Spreen, G., and Pang, S.: Arctic sea ice circulation and drift speed: Decadal trends and ocean currents, J. Geophys. Res., 118, 2408-2425, https://doi.org/10.1002/jgrc.20191, 2013.

Langehaug, H., Geyer, F., Smedsrud, L., and Gao, Y.: Arctic sea ice decline and ice export in the CMIP5 historical simulations, Ocean Model., 71, 114-126, 2013.

Large, W. G. and Yeager, S. G.: The global climatology of an interannually varying air-sea flux data set, Clim. Dynam., 33, 341364, https://doi.org/10.1007/s00382-008-0441-3, 2009.

Lavergne, T., Eastwood, S., Teffah, Z., Schyberg, H., and Breivik, L.-A.: Sea ice motion from low-resolution satellite sensors: An alternative method and its evaluation in the Arctic, J. Geophys. Res., 115, C10032, https://doi.org/10.1029/2009JC005958, 2010.

Leppäranta, M.: The drift of sea ice (Second Edition), Springer, 2011.

Lindsay, R. and Schweiger, A.: Arctic sea ice thickness loss determined using subsurface, aircraft, and satellite observations, The Cryosphere, 9, 269-283, https://doi.org/10.5194/tc-9-269-2015, 2015.

Lipscomb, W. H., Hunke, E. C., Maslowski, W., and Jakacki, J.: Ridging, strength, and stability in highresolution sea ice models, J. Geophys. Res., 112, C03S91, https://doi.org/10.1029/2005JC003355, 2007.

Madec, G.: NEMO ocean engine: Note du Pôle de modélisation de l'Institut Pierre-Simon Laplace No 27, available at: http://www. nemo-ocean.eu/About-NEMO/Reference-manuals (last access: 12 April 2016), 2016.

Massonnet, F., Goosse, H., Fichefet, T., and Counillon, F.: Calibration of sea ice dynamic parameters in an ocean-sea ice model using an ensemble Kalman filter, J. Geophys. Res., 119, 41684184, https://doi.org/10.1002/2013JC009705, 2014.

Massonnet, F., Bellprat, O., Guemas, V., and Doblas-Reyes, F. J.: Using climate models to estimate the quality of global observational data sets, Science, 354, 452-455, https://doi.org/10.1126/science.aaf6369, 2016.

Notz, D.: Sea-ice extent and its trend provide limited metrics of model performance, The Cryosphere, 8, 229-243, https://doi.org/10.5194/tc-8-229-2014, 2014.

Notz, D.: How well must climate models agree with observations?, Philosophical Transactions of the Royal Society of London, Series A: Mathematical and Physical Sciences, 373, https://doi.org/10.1098/rsta.2014.0164, 2015.
Notz, D., Jahn, A., Holland, M., Hunke, E., Massonnet, F., Stroeve, J., Tremblay, B., and Vancoppenolle, M.: The CMIP6 SeaIce Model Intercomparison Project (SIMIP): understanding sea ice through climate-model simulations, Geosci. Model Dev., 9, 3427-3446, https://doi.org/10.5194/gmd-9-3427-2016, 2016.

Olason, E. and Notz, D.: Drivers of variability in Arctic sea-ice drift speed, J. Geophys. Res., 119, 5755-5775, https://doi.org/10.1002/2014JC009897, 2014.

Overland, J. E. and Pease, C. H.: Modeling ice dynamics of coastal seas, J. Geophys. Res., 93, 15619-15637, https://doi.org/10.1029/JC093iC12p15619, 1988.

Polyakov, D. V., Walsh, J. E., and Kwok, R.: Recent changes of Arctic multiyear sea ice coverage and the likely causes, B. Am. Meteorol. Soc., 93, 145-151, https://doi.org/10.1175/BAMS-D11-00070.1, 2012.

Rampal, P., Weiss, J., Marsan, D., and Bourgoin, M.: Arctic sea ice velocity field: General circulation and turbulent-like fluctuations, J. Geophys. Res., 114, C10014, https://doi.org/10.1029/2008JC005227, 2009.

Rampal, P., Weiss, J., Dubois, C., and Campin, J.-M.: IPCC climate models do not capture Arctic sea ice drift acceleration: Consequences in terms of projected sea ice thinning and decline, J. Geophys. Res., 116, C00D07, https://doi.org/10.1029/2011JC007110, 2011.

Rothrock, D. A.: The energetics of the plastic deformation of pack ice by ridging, J. Geophys. Res., 80, 4514-4519, https://doi.org/10.1029/JC080i033p04514, 1975.

Rothrock, D. A. and Wensnahan, M.: The accuracy of sea-ice drafts measured from U.S. Navy submarines, J. Atmos. Ocean Tech., 24, 1936-1949, https://doi.org/10.1175/JTECH2097.1, 2007.

Rothrock, D. A., Percival, D. B., and Wensnahan, M.: The decline in Arctic sea-ice thickness: Separating the spatial, annual, and interannual variability in a quarter century of submarine data, J. Geophys. Res., 113, C05003, https://doi.org/10.1029/2007JC004252, 2008.

Rousset, C., Vancoppenolle, M., Madec, G., Fichefet, T., Flavoni, S., Barthélemy, A., Benshila, R., Chanut, J., Levy, C., Masson, S., and Vivier, F.: The Louvain-La-Neuve sea ice model LIM3.6: global and regional capabilities, Geosci. Model Dev., 8, 29913005, https://doi.org/10.5194/gmd-8-2991-2015, 2015.

Schweiger, A., Lindsay, R., Zhang, J., Steele, M., Stern, H., and Kwok, R.: Uncertainty in modeled Arctic sea ice volume, J. Geophys. Res., 116, C00D06, https://doi.org/10.1029/2011JC007084, 2011.

Smedsrud, L. H., Halvorsen, M. H., Stroeve, J. C., Zhang, R., and Kloster, K.: Fram Strait sea ice export variability and September Arctic sea ice extent over the last 80 years, The Cryosphere, 11, 65-79, https://doi.org/10.5194/tc-11-65-2017, 2017.

Smith, D.: Extraction of winter total sea ice concentration in the Greenland and Barents Seas from SSM/I data, Int. J. Remote Sens., 17, 2625-2646, 1996.

Spreen, G., Kern, S., Stammer, D., and Hansen, E.: Fram Strait sea ice volume export estimated between 2003 and 2008 from satellite data, Geophys. Res. Lett., 36, L19502, https://doi.org/10.1029/2009GL039591, 2009.

Spreen, G., Kwok, R., and Menemenlis, D.: Trends in Arctic sea ice drift and role of wind forcing: 1992-2009, Geophys. Res. Lett., 38, L19501, https://doi.org/10.1029/2011GL048970, 2011. 
Spreen, G., Kwok, R., Menemenlis, D., and Nguyen, A. T.: Sea-ice deformation in a coupled ocean-sea-ice model and in satellite remote sensing data, The Cryosphere, 11, 1553-1573, https://doi.org/10.5194/tc-11-1553-2017, 2017.

Steele, M., Zhang, J., Rothrock, D., and Stern, H.: The force balance of sea ice in a numerical model of the Arctic Ocean, J. Geophys. Res.-Oceans, 102, 21061-21079, https://doi.org/10.1029/97JC01454, 1997.

Stroeve, J., Barrett, A., Serreze, M., and Schweiger, A.: Using records from submarine, aircraft and satellites to evaluate climate model simulations of Arctic sea ice thickness, The Cryosphere, 8, 1839-1854, https://doi.org/10.5194/tc-8-1839-2014, 2014.

Stroeve, J. C., Serreze, M. C., Holland, M. M., Kay, J. E., Malanik, J., and Barrett, A. P.: The Arctic's rapidly shrinking sea ice cover: a research synthesis, Climatic Change, 110, 1005-1027, https://doi.org/10.1007/s10584-011-0101-1, 2012.

Sumata, H., Lavergne, T., Girard-Ardhuin, F., Kimura, N., Tschudi, M. A., Kauker, F., Karcher, M., and Gerde, R.: An intercomparison of Arctic ice drift products to deduce uncertainty estimates, J. Geophys. Res., 119, 4887-4921, https://doi.org/10.1002/2013JC009724, 2014.

Szanyi, S., Lukovich, J. V., Barber, D. G., and Haller, G.: Persistent artifacts in the NSIDC ice motion data set and their implications for analysis, Geophys. Res. Lett., 43, 10800-10807, https://doi.org/10.1002/2016GL069799, 2016.

Tandon, N. F., Kushner, P. J., Docquier, D., Wettstein, J. J., and $\mathrm{Li}, \mathrm{C} .:$ Reassessing sea ice drift and its relationship to long term Arctic sea ice loss in coupled climate models, J. Geophys. Res., in review, 2017.

Tremblay, L.-B. and Hakakian, M.: Estimating the Sea Ice Compressive Strength from Satellite-Derived Sea Ice Drift and NCEP Reanalysis Data, J. Phys. Oceanogr., 36, 2165-2172, https://doi.org/10.1175/JPO2954.1, 2006.
Tschudi, M., Fowler, C., Maslanik, J., Stewart, J. S., and Meier, W.: Polar Pathfinder Daily $25 \mathrm{~km}$ EASEGrid Sea Ice Motion Vectors, Version 3, available at: https://doi.org/10.5067/O57VAIT2AYYY (last access: 26 June 2017), 2016.

Ungermann, M., Tremblay, L. B., Martin, T., and Losch, M.: Impact of the ice strength formulation on the performance of a sea ice thickness distribution model in the Arctic, J. Geophys. Res., 122, 2090-2107, https://doi.org/10.1002/2016JC012128, 2017.

Vancoppenolle, M., Fichefet, T., Goosse, H., Bouillon, S., Madec, G., and Morales Maqueda, M. A.: Simulating the mass balance and salinity of Arctic and Antarctic sea ice. 1. Model description and validation, Ocean Model., 27, 33-53, https://doi.org/10.1016/j.ocemod.2008.10.005, 2009.

Vaughan, D., Comiso, J., Allison, I., Carrasco, J., Kaser, G., Kwok, R., Mote, P., Murray, T., Paul, F., Ren, J., Rignot, E., Solomina, O., Steffen, K., and Zhang, T.: Observations: Cryosphere, in: Climate Change 2013: The Physical Science Basis. Contribution of Working Group I to the Fifth Assessment Report of the Intergovernmental Panel on Climate Change, edited by: Stocker, T. F., Qin, D., Plattner, G.-K., Tignor, M., Allen, S. K., Boschung, J., Nauels, A., Xia, Y., Bex, V., and Midgley, P. M., Cambridge University Press, Cambridge, United Kingdom and New York, NY, USA, 2013.

Vihma, T., Tisler, P., and Uotila, P.: Atmospheric forcing on the drift of Arctic sea ice in 1989-2009, Geophys. Res. Lett., 39, L02501, https://doi.org/10.1029/2011GL050118, 2012.

Zhang, J. and Rothrock, D. A.: Modeling global sea ice with a thickness and enthalpy distribution model in generalized curvilinear coordinates, Mon. Weather Rev., 131, 845-861, 2003.

Zygmuntowska, M., Rampal, P., Ivanova, N., and Smedsrud, L. H.: Uncertainties in Arctic sea ice thickness and volume: new estimates and implications for trends, The Cryosphere, 8, 705-720, https://doi.org/10.5194/tc-8-705-2014, 2014. 